\title{
30. HYDROTHERMAL MOUNDS AND YOUNG OCEAN CRUST OF THE GALAPAGOS: PRELIMINARY DEEP SEA DRILLING RESULTS1
}

\author{
J. Honnorez, ${ }^{2}$ R. P. Von Herzen, ${ }^{3}$ T. J. Barrett, ${ }^{4}$ P. E. Borella, ${ }^{5}$ S. A. Moorby, ${ }^{6}$ S. Karato,${ }^{7}$ and \\ Remainder of Leg 70 Shipboard Party ${ }^{8}$
}

\begin{abstract}
A total of 32 holes at five sites near $1^{\circ} \mathrm{N}, 86^{\circ} \mathrm{W}$ drilled on Deep Sea Drilling Project (DSDP) Leg 70 (NovemberDecember 1979) provide unique data on the origin of the hydrothermal mounds on the southern flank of the Galapagos Spreading Center. Hydrothermal sediments, primarily Mn-oxide and nontronite, are restricted to the immediate vicinity of the mounds $(<100 \mathrm{~m})$ and are probably formed by the interaction of upward-percolating hydrothermal solutions with seawater and pelagic sediments above locally permeable zones of ocean crust. Mounds as high as 25 meters form in less than a few hundred thousand years, and geothermal and geochemical gradients indicate that they are actively forming today. The lack of alteration of upper basement rocks directly below the mounds and throughout the Galapagos region indicates that the source of the hydrothermal solutions is deeper in the crust.
\end{abstract}

\section{INTRODUCTION}

Leg 70 of the Deep Sea Drilling Project (DSDP) was dedicated to the overall study of active hydrothermal regimes in oceanic ridge flanks. Particularly emphasized during the first part of Leg 70 was the study of a very young, "open," hydrothermal system close to the actively spreading Galapagos Ridge, in contrast to the slightly older "closed" system south of the Costa Rica Rift, investigated during the second part of Leg 70.

The Galapagos Spreading Center is one of the best surveyed regions of the deep-sea floor. Heat-flow measurements (Sclater and Klitgord, 1973; Sclater et al., 1974; Williams et al., 1974; Green et al., 1981), magnetic profiles (Sclater and Klitgord, 1973; Klitgord and Mudie, 1974), bathymetric surveys (Hey et al., 1977; Lonsdale, 1977; Allmendinger and Riis, 1979), geochemical studies of material collected by dredging (Moore and Vogt, 1976; Clague et al., 1981), and several diving expeditions with the submersible Alvin (Corliss et al., 1979a, b; Edmond et al., 1979a,b) show that the Galapagos Spreading Center is a site of intense hydrothermal activity. The half-spreading rate calculated from the magnetic anomalies has been about $3.4 \mathrm{~cm} / \mathrm{y}$. for the past two million years.

The southern flank of the Galapagos Spreading Center is characterized by a regularly varying heat-flow pattern, strongly lineated subparallel to the spreading axis, with alternating discharge and recharge zones corresponding to 5- to 15-km-wide convection cells (Green, 1980; Green et al., 1981).

\footnotetext{
${ }^{1}$ Honnorez, J., Von Herzen, R. P., et al., Init. Repts. DSDP, 70: Washington (U.S. Govt, Printing Office)

School of Marine and Atmospheric Sciences, University of Miami, Miami, Florida.

3 Department of Geology and Geophysics, Woods Hole Oceanographic Institution, Woods Hole, Massachusetts.

${ }^{4}$ Department of Geology, University of Toronto, Toronto, Canada.

5 Deep Sea Drilling Project, Scripps Institution of Oceanography, La Jolla, California.

6 Department of Geology, Imperial College, London, United Kingdom.

7 Ocean Research Institute, University of Tokyo, Nakano, Tokyo, Japan.

8 Affiliations of the Shipboard Scientific Party are listed in the site chapters.
}

Unique features discovered during deep-tow surveys and sampled later using the submersible Alvin are the hydrothermal mounds south of the spreading axis (Klitgord and Mudie, 1974; Lonsdale, 1977; Corliss et al., 1979a; Williams et al., 1974). The Galapagos mounds field occupies an area 18 to $32 \mathrm{~km}$ south of the Galapagos spreading axis, near $1^{\circ} \mathrm{N}, 86^{\circ} \mathrm{W}$ (Fig. 1). The basement age in the mounds area, given a half-spreading rate of $3.4 \mathrm{~cm} / \mathrm{y}$, ranges from $0.5 \mathrm{~m} . \mathrm{y}$. in the north to $0.9 \mathrm{~m} . \mathrm{y}$. in the south (Williams et al., 1979). The mounds often occur as more or less continuous chains with a preferential orientation sub-parallel to the spreading axis. They sometimes appear to be located above small vertical displacements in the basement, presumably fault scarps. The mounds are from 5 to 20 meters higher than the general level of the adjacent seafloor, and 25 to 100 meters in diameter (or width) at their bases, with generally steep slopes up to $45^{\circ}$. The mounds are sometimes surrounded by a moat less than 5 meters deep. The mound surface is generally dark colored with local bright yellow spots and streaks compared to the light tan or gray surrounding pelagic oozes (Williams et al., 1979).

Leg 54 had drilled a total of five holes at Sites 424 and 425 into a hydrothermal mound south of the Galapagos Spreading Center and a 2.5-m.y.-old low heatflow area north of the mounds center (Hekinian, Rosendahl et al., 1978). Geochemical and mineralogical studies of the hydrothermal deposits recovered on Leg 54 have been carried out by Hekinian et al. (1978), Dymond et al. (1980), Hoffert et al. (1980), Natland et al. (1979), and Schrader et al. (1980). Natland et al. (1979) also presented a stratigraphic interpretation suggesting that the hydrothermal sediments were distributed as a uniform blanket throughout the mounds area. However, interpretations were constrained by the fact that the mounds sedimentary sections were extremely disturbed as a result of rotary drilling through a thin, unconsolidated sediment cover composed of several strata with contrasting mechanical properties (Hekinian et al., 

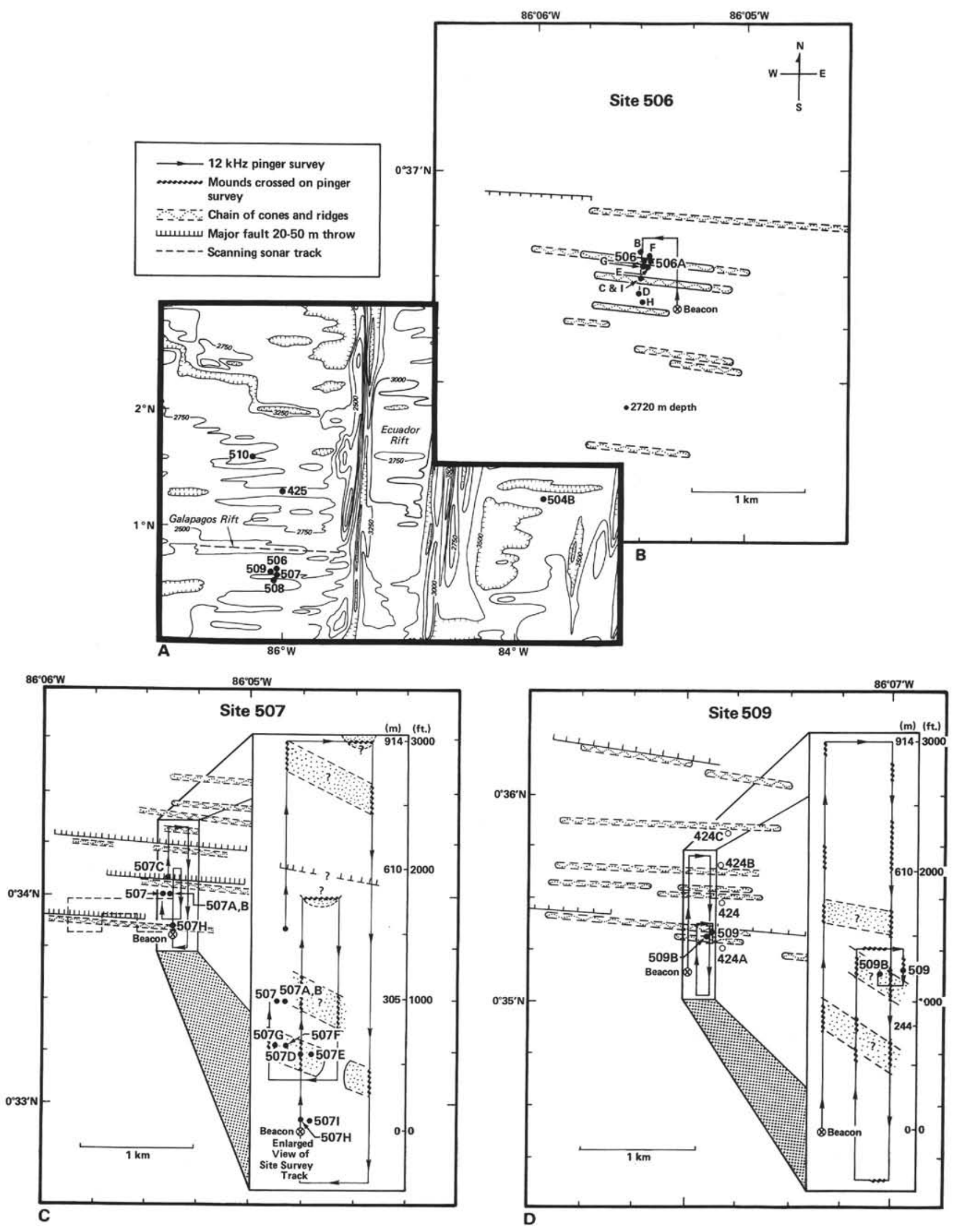

Figure 1. Site locality and detailed site surveys. 
1978; Natland et al., 1979). Core recovery of hydrothermal sediments on Leg 54 had been limited for the same reasons. Hence, the first major objective of Leg 70 was to recover complete, undisturbed sediment sections through the mounds in order to compare them with their equivalents from the sedimentary cover at high heat-flow areas without mounds and at low heat-flow sites of various ages.

Another major objective of Leg 70 was to carry out in situ measurements in a series of environments characterized by high conductive heat flow, with and without hydrothermal mounds, and in relatively low heat-flow areas nearby. A third objective was to recover basement rocks from beneath the mounds and their environs to determine the nature and extent of basalt alteration by the hydrothermal fluids which generate the mounds. As had already been found on Leg 54, drilling into basement proved difficult during Leg 70 because of the extremely fragmented nature of the basement. Our maximum penetration into hard rock was 19 meters at Site 510 , with only 7.2 meters of basalt recovered.

In the region south of the Galapagos Spreading Center, profiles show that the thickness of the sediment cover increases rapidly and regularly away from the spreading axis. The rapid increase in the thickness of the sediment cover results from the high sedimentation rate in this area, which is presently beneath the equatorial high biological productivity zone.

Two seismic reflectors were observed at sub-bottom depths of about 7 and 15 meters over much of the region south of the Galapagos Spreading Center (Lonsdale, 1977). They were ascribed by Lonsdale to ash layers, deposited about 140,000 and 300,000 years ago, respectively. On the other hand, the Leg 54 scientific party had suggested that these reflectors result from the regional extension of the same hydrothermal sediments which form the mounds (Natland et al., 1979). Hence yet another objective of Leg 70 was to determine the actual nature of the two reflectors by correlating undisturbed stratigraphic sections of the sediment cover collected with the hydraulic piston corer (HPC) both in and around the mounds and away from them.

\section{STRATIGRAPHY}

The stratigraphy of the sequences recovered by the HPC is shown in Figure 2 (Honnorez et al., 1981). At the mounds sites, the sediments can be divided into three units, as described in detail by Borella et al. (this volume). Unit III, the bottom unit, consists of foraminifer-nannofossil ooze varying from 7 to 17 meters in thickness. The lower boundary of this unit is the contact with basalt basement, and the upper contact is gradational with Unit II, the middle unit. In the upper part of Unit III, nontronite-rich mottles are common for one to several meters below the lowest well-defined area of nontronite.

Unit II is composed of interbedded and locally intermixed hydrothermal sediments and pelagic oozes. It ranges in thickness on the mounds sites from 12 to 28 meters. Nontronite is the dominant hydrothermal sediment in Holes 506, 506C, and 507D, with only a few scattered Mn-oxide crust fragments occurring intermixed with nontronite in the upper few meters of the unit. In Hole 509B, a 1.4-meter-thick layer of Mn-oxide fragments occurs at the top of Unit II, overlying the nontronite. Hydrothermal sediment is present in Holes $506 \mathrm{D}$ and $507 \mathrm{~F}$ as single nontronitic layers 1 to 2 meters in thickness, but such sediment is absent from Holes $507 \mathrm{~B}, 507 \mathrm{H}$, and 509 . One- to five-meter-thick nontronitic layers, consisting essentially of $100 \%$ nontronite granules, alternate with units of pelagic sediment mostly $<2$ meters in thickness. The contact between the two sediment types is generally gradational over about 10 to $30 \mathrm{~cm}$; fine-grained compact nontronite constitutes the transitional material. In a few cases, a sharp contact exists between granular nontronite and underlying pelagic sediment, but since these are at core tops, it is likely that the granules represent contaminating material which had fallen downhole after the previous core was taken.

Unit I consists of a siliceous foraminifer-nannofossil ooze and varies from 0.3 to 3.0 meters in thickness on the mounds. On the two off-mounds sites with thin nontronite intervals (Holes 506D and 507F), Unit $\mathrm{I}$ is 3 to 5 meters thick. A characteristic feature of this unit in all holes is an uppermost 20 - to 50 -cm-thick layer of oxidized brown ooze.

It is clear from Figure 2 that the intervals of hydrothermal sediment are restricted almost entirely to the mounds themselves, with only a few thin layers extending up to 50 meters laterally from some mounds, and interfingering with normal pelagic sediment at off-mounds sites. Hence, the suggestion that hydrothermal sediments form a unit of regional extent centered at the mounds (Natland et al., 1979) can be refuted. Furthermore, the very localized nature of the Mn-oxide crusts, present to a significant degree only at the top of one of the four mounds holes, makes unlikely the suggestion by Schrader et al. (1980) that the mounds area contains $1 / 13$ of the world's estimated reserve of manganese.

\section{SEDIMENTOLOGY AND GEOCHEMISTRY}

The sediments recovered on Leg 70 can be divided into hydrothermal sediments, represented by Mn-oxide crusts and green nontronitic clays, and pelagic oozes. The oozes are essentially foraminifer-nannofossil oozes which can be further subdivided on the basis of the proportion of siliceous and calcareous microfossils present. A thin surface layer of brownish oxidized ooze also occurs in all cores.

\section{Hydrothermal Sediments}

\section{Manganese-Oxide Crusts}

The Mn-oxide crusts consist of brownish black, flat to saucer-shaped, angular fragments, ranging in size from 1 to $4 \mathrm{~cm}$ in width and 1 to $5 \mathrm{~mm}$ in thickness. Surface textures are finely granular, though some samples show a botryoidal-concretionary growth pattern. The fragments are brittle, and freshly broken pieces show in cross section dense metallic material, sometimes microlaminated and often with a thin $(<2 \mathrm{~mm})$ coating of soft porous black Mn oxides on one or both surfaces. 


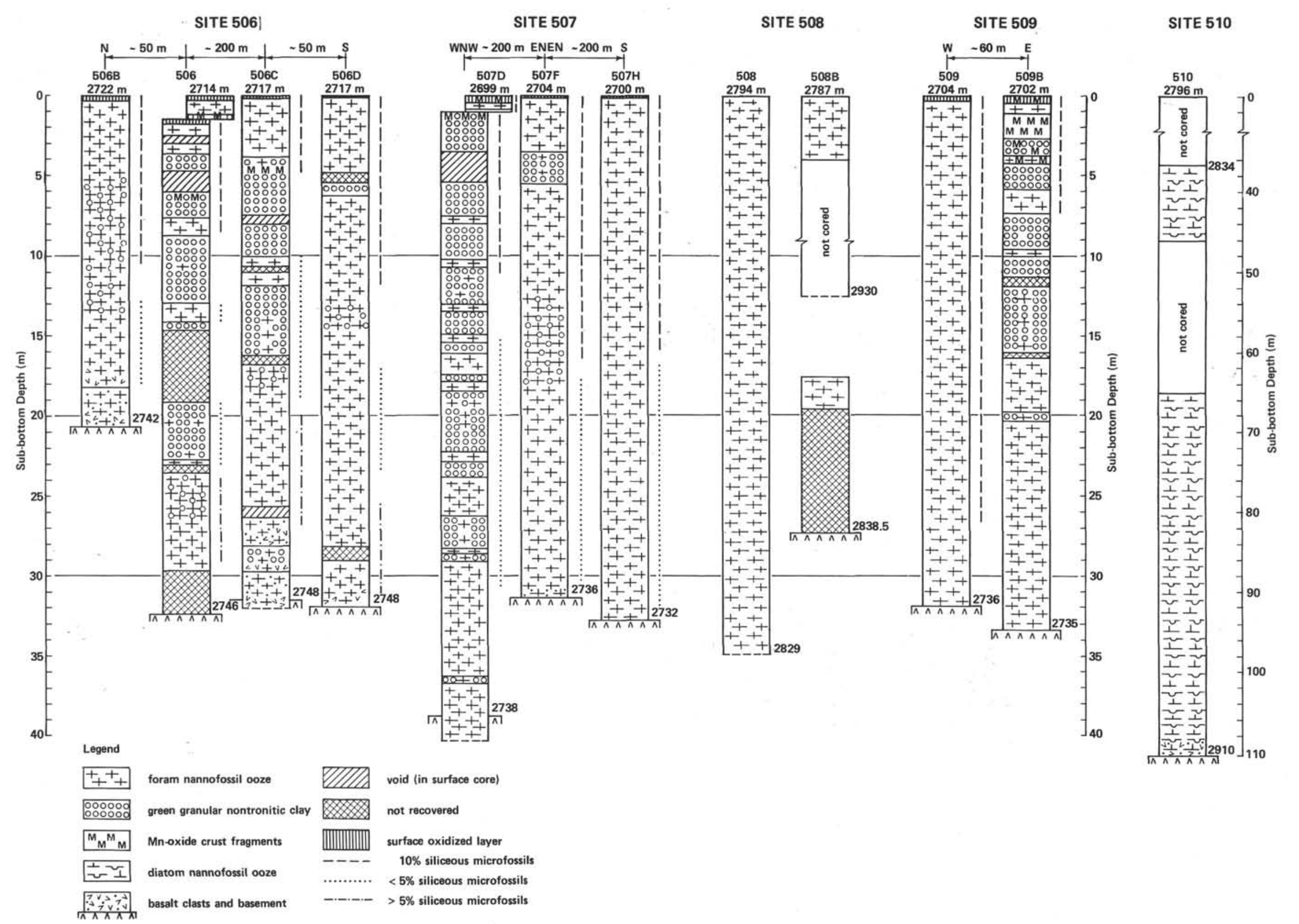

Figure 2. Generalized stratigraphic summary of the mounds sediments (Sites 506-510) in the Galapagos hydrothermal area. 
$\mathrm{X}$-ray diffraction (XRD) analysis indicates that todorokite is the major crystalline manganese phase present. However, it is possible that amorphous $\mathrm{Mn}-\mathrm{Fe}$ oxide phases also could be present within the crusts which would be undetectable by XRD. One thin section revealed $\mathrm{Fe}$ oxide-hydroxide material intergrown with a zoned Mn-oxide crust (Borella et al., this volume) but the presence of such minerals was not confirmed by XRD studies.

Varentsov et al. (this volume) pointed out that todorokite is in a somewhat less oxidized state than birnessite and $\delta-\mathrm{MnO}_{2}$. According to Corliss et al. (1978), most Mn-oxide crusts dredged from present mounds surfaces are represented dominantly by birnessite, with only minor todorokite present. Because of this, Varentsov et al. (this volume) suggest that the Mn crusts sampled on Leg 70 have formed in a somewhat less oxidized environment, possibly as a result of growing at a slightly subsurface level, or under the influence of discharging hydrothermal solutions.

Based on uranium series disequilibrium age-dating techniques, Lalou et al. (this volume) suggest that the manganese-oxide crusts formed on top of the mounds from 20,000 to 60,000 years ago. These Mn encrustations are most likely a modification of pre-existing sediment. Further, Lalou et al. (this volume) suggest that manganese precipitated either (1) when hydrothermal flow slowed down sufficiently to change the sediment/ water interface from a reducing to an oxidizing state, or (2) when the hydrothermal system changed from a rock dominated phase of iron and silica precipitation to a water dominated phase leading to manganese precipitation (Natland, 1979).

The average chemical composition of the Mn-oxide crusts is given in Table 1, together with the composition of Mn crusts and nodules from various localities reported by other workers (Moorby and Cronan, this volume). The table indicates that relative to crusts from the mounds analyzed by Hekinian et al. (1978) and Schrader et al. (1980), the Leg 70 crusts are significantly lower in $\mathrm{SiO}_{2}$ and higher in $\mathrm{Al}, \mathrm{Fe}$, and $\mathrm{V}$. As noted by Moorby and Cronan (this volume), this is not likely to be the result of a greater admixture of diluting pelagic sediment because $\mathrm{Ca}$ contents indicate that little if any carbonate material is incorporated. These discrepancies can be ascribed to systematic analytical differences, regional heterogeneities of the Mn crust, or a combination of both.

Concentrations of $\mathrm{Ni}, \mathrm{Cu}$, and $\mathrm{Zn}$ in the crusts are generally less than $200 \mathrm{ppm}, \mathrm{Pb}$ less than $100 \mathrm{ppm}$, and Co less than $20 \mathrm{ppm}$ (Table 1). No crusts showed the relatively high $\mathrm{Ni}, \mathrm{Cu}$, and $\mathrm{Zn}$ values which were reported for several crusts analyzed by Corliss et al. (1978). Low trace-element content of Mn-rich material has been considered (cf. Bonatti et al., 1972; Toth, 1980 ) as evidence for rapid accumulation in hydrothermal as compared to normal seawater environments. In the case of $\mathrm{Zn}$, however, Moorby and Cronan (this volume) suggest, on the basis of a high $\mathrm{Zn} / \mathrm{Co}$ ratio (Toth, 1980 ), that $\mathrm{Zn}$ in the Mn crusts is of predominantly hydrothermal origin. Moorby and Cronan (this volume) also note that the Leg 70 crusts contain comparatively high levels of $\mathrm{Li}$, plus striking enrichments in Mo comparable to Mo enrichments in hydrogenous nodules from the Northeast Pacific.

Mn-oxide-rich mud, found only near the surface of the Hole 509B mound, has a composition intermediate between Mn-oxide crusts and normal pelagic ooze (Tables 1,2$)$. This conforms with the visual observation that the mud consists of microaggregates of black Mn oxides (with minor yellowish brown Fe-oxide microaggregates) dispersed throughout pelagic ooze. An interesting feature of this mud is that relative to normal pelagic ooze (and to oxidized surface sediment), it has similar $\mathrm{SiO}_{2}$ contents, but significantly lower $\mathrm{Ca}$ and significantly higher Mn contents. This suggests that the carbon-

Table 1. Comparison of bulk composition of Mn-oxide crusts and sediments from Leg 70 with other Mn-rich deposits (modified from Moorby and Cronan, this volume).

\begin{tabular}{|c|c|c|c|c|c|c|c|c|c|c|c|c|c|c|c|c|c|c|}
\hline Samples & $\underset{(\%)}{K}$ & $\begin{array}{l}\mathrm{Mg} \\
(\%)\end{array}$ & $\begin{array}{l}\mathrm{Ca} \\
(\%)\end{array}$ & $\begin{array}{c}\mathrm{Al} \\
(\%)\end{array}$ & $\underset{(\%)}{\mathrm{SiO}_{2}}$ & $\begin{array}{l}\mathrm{Mn} \\
(\%)\end{array}$ & $\begin{array}{l}\mathrm{Fe} \\
(\%)\end{array}$ & $\underset{(\mathrm{ppm})}{\mathrm{Li}}$ & $\begin{array}{c}\mathrm{Sr} \\
(\mathrm{ppm})\end{array}$ & $\underset{(\mathrm{ppm})}{\mathrm{P}}$ & $\underset{(\mathrm{ppm})}{\mathrm{Ti}}$ & $\begin{array}{c}\mathrm{V} \\
(\mathrm{ppm})\end{array}$ & $\begin{array}{c}\text { Co } \\
(\mathrm{ppm})\end{array}$ & $\begin{array}{c}\mathrm{Ni} \\
(\mathrm{ppm})\end{array}$ & $\underset{(\mathrm{ppm})}{\mathrm{Cu}}$ & $\underset{(\mathrm{ppm})}{\mathrm{Zn}}$ & $\underset{(\mathrm{ppm})}{\mathrm{Pb}}$ & $\begin{array}{c}\text { Mo } \\
\text { (ppm) }\end{array}$ \\
\hline $\begin{array}{l}\text { Mn-Crusts } \\
\quad(\text { Av. }=8)\end{array}$ & 0.71 & 1.6 & 0.98 & 0.24 & $\begin{array}{c}3.1 \\
(n=2)\end{array}$ & 44.0 & 0.66 & 100 & 660 & 1200 & 28 & 107 & 13 & 124 & 80 & 93 & 56 & 540 \\
\hline $\begin{array}{l}\text { Mn-rich Mud } \\
\quad(\text { Av. }=4)\end{array}$ & 0.39 & 1.3 & 8.7 & 1.2 & $\begin{array}{l}14.0 \\
(\mathrm{n}=2)\end{array}$ & 21.8 & 1.3 & 6.4 & 675 & 1020 & 475 & 85 & 12 & 200 & 115 & 215 & 58 & 160 \\
\hline Mounds Mn-Crust ${ }^{\mathrm{a}}$ & 0.41 & 2.5 & 4.1 & 0.12 & 0.81 & 45.3 & 0.22 & - & 390 & - & 60 & 18 & 11 & 83 & 48 & 160 & - & - \\
\hline Mounds Mn-Crust $\mathrm{b}$ & 0.23 & 1.9 & 0.98 & 0.41 & 0.71 & 54.9 & 0.24 & - & - & - & - & - & - & - & - & - & - & - \\
\hline Mounds Mn-Crust ${ }^{\mathrm{c}}$ & 0.6 & 1.4 & 1.5 & 0.19 & 1.7 & 50.0 & 0.26 & - & - & - & - & - & 4.7 & 470 & 100 & 378 & - & - \\
\hline Gulf of Adend & 1.4 & 1.8 & 1.5 & 0.69 & 7.8 & 37.9 & 2.7 & - & 320 & - & 1070 & - & 30 & 395 & 82 & 310 & - & - \\
\hline Various Localitiese & - & - & - & 0.13 & 0.92 & 45.6 & 0.18 & - & - & - & - & - & 17 & 640 & 320 & 1030 & 10 & - \\
\hline $\begin{array}{l}\text { Hydrogenous Mn Nodules, } \\
\text { Pacific Oceanf }\end{array}$ & 0.75 & 1.7 & 2.0 & 3.1 & 17.8 & 19.8 & 12.0 & - & 850 & 2350 & 6700 & 530 & 3400 & 6300 & 3900 & 680 & 850 & 440 \\
\hline $\begin{array}{l}\text { Continental Borderland } \\
\text { Modulesg }\end{array}$ & - & - & - & - & - & 34.0 & 1.6 & - & - & - & 600 & 310 & 75 & 970 & 650 & - & 60 & 720 \\
\hline
\end{tabular}

a Data from: Schrader, E. L., Furbish, W. J., Mattey, D., and May, J. A., 1980. Geochemistry and carbonate petrology of selected sediment samples from DSDP Leg 54, Eastern Pacific. In Rosendahl, B. R., Hekinian, R, et al, Init, Repts, DSDP, 54: Washington (U.S. Govt. Printing Office), 319-328.

b Data from: Hekinian, R., Rosendahl, B. R., Cronan, D. S., Dmitriev, Y., Fodor, R. V., Goll, R. M., Hoffert, M., Humphris, S. E., Mattey, D. P., Natland, J., Petersen, N., Rog. genthen, W., Schrader, E., L., Srivastava, R. K., and Warren, N., 1978. Hydrothermal deposits and associated basement rocks from the Galapagos Spreading Centre. Oceanol. Ac-
get ta, $1: 473-482$.

c Data from: Corliss, J. B., Lyle, M., Dymond, J., and Crane, K., 1978. The chemistry of hydrothermal mounds near the Galapagos Rift. Earth Planet, Sci. Lett., 40:12-24. d Data from: Cann, J. R., Winter, C. K., and Pritchard, R. G., 1977. A hydrothermal deposit from the floor of the Gulf of Aden. Min. Mag., 41:193-199.

e Data from: Toth, J. R., 1980. Deposition of submarine crusts rich in manganese and iron. Bull. Geol. Soc. Am., 91:44-54.

f Data from: Cronan, D. S., 1975. Manganese nodules and other ferromanganese oxide deposits. In Riley, J. P., and Chester, R. (Eds.), Chemical Oceanography (Vol. 5): New York (Wiley Interscience), 217-263.

8 Data from: Cronan, D. S., 1972. Regional geochemistry of ferromanganese nodules from the world ocean. In Horn, D. R. (Ed.), Papers from a Conference on Ferromanganese Deposits on the Ocean Floor: Washington, D.C. (National Science Foundation), pp. 19-30. 
Table 2. Average bulk chemical composition of the different sediment types recognized on Leg 70. Figures in parentheses are data recalculated on a carbonate-free basis. (From Moorby and Cronan, this volume.)

\begin{tabular}{|c|c|c|c|c|c|c|c|c|}
\hline Element & $\begin{array}{r}\mathrm{Pe} \\
\text { Sedi }\end{array}$ & $\begin{array}{l}\text { lagic } \\
\text { ments }\end{array}$ & $\begin{array}{l}\text { Surface } \\
\text { Sediment }\end{array}$ & $\begin{array}{c}\text { Basal } \\
\text { Sediment }\end{array}$ & Nontronites & $\begin{array}{c}\text { Transitional } \\
\text { Sediment }\end{array}$ & $\begin{array}{l}\text { Mn-oxide- } \\
\text { rich } \\
\text { Sediment }\end{array}$ & Mottles \\
\hline \multicolumn{9}{|c|}{$(\%)$} \\
\hline K & \multicolumn{2}{|c|}{$0.26(0.79)$} & 0.25 & 0.22 & 1.5 & 1.1 & 0.60 & 0.47 \\
\hline $\mathrm{Mg}$ & \multirow{2}{*}{\multicolumn{2}{|c|}{$0.70(2.1)$}} & 0.65 & 0.77 & 2.2 & 2.1 & 1.5 & 1.0 \\
\hline $\mathrm{Ca}$ & 26.8 & & 23.8 & 30.7 & 0.40 & 5.4 & 3.6 & 24.7 \\
\hline Al & 1.2 & (3.7) & 1.2 & 1.16 & 0.28 & 2.2 & 0.56 & 1.1 \\
\hline $\mathrm{SiO}_{2}$ & \multicolumn{2}{|c|}{$14.8 \quad(44.8)$} & 15.2 & 10.0 & 43.5 & 35.9 & 8.6 & 0.0 \\
\hline $\mathrm{Mn}^{2}$ & \multicolumn{2}{|c|}{$0.26(0.79)$} & 2.1 & 0.19 & 0.11 & 0.19 & 38.6 & 0.23 \\
\hline $\mathrm{Fe}$ & \multicolumn{2}{|c|}{$1.25(3.8)$} & 1.26 & 1.48 & 20.2 & 9.96 & 0.87 & 3.8 \\
\hline \multicolumn{9}{|c|}{ (ppm) } \\
\hline $\mathrm{Li}$ & 8.4 & (25) & 5.1 & 7.2 & 8.4 & 21. & 69 & 8.7 \\
\hline $\mathrm{Be}$ & 0.3 & $(0.9)$ & 0.3 & 0.3 & 0.27 & 0.5 & 0.25 & 0.34 \\
\hline $\mathrm{Cd}$ & 1.7 & $(5.2)$ & 1.6 & 1.6 & 4.2 & 2.7 & 1.7 & - \\
\hline $\mathrm{Sr}$ & 960 & $(2900)$ & 1050 & 1160 & 47 & 310 & 665 & 780 \\
\hline $\mathrm{Ti}$ & 570 & (1730) & 520 & 715 & 117 & 990 & 777 & 495 \\
\hline $\mathrm{v}$ & 67 & (200) & 50 & 58 & 17 & 95 & 100 & 42 \\
\hline $\mathrm{Cr}$ & 30 & (91) & 30 & 26 & 31 & 47 & 37 & 32 \\
\hline Co & 9 & (27) & 12 & 12 & 3 & 10 & 13 & 6 \\
\hline $\mathrm{Ni}$ & 85 & (260) & 161 & 63 & 17 & 77 & 150 & 48 \\
\hline $\mathrm{Cu}$ & 84 & (255) & 102 & 58 & 21 & 118 & 92 & 58 \\
\hline $\mathrm{Zn}$ & 140 & (420) & 177 & 76 & 56 & 171 & 134 & 102 \\
\hline $\mathrm{Pb}$ & 17 & (52) & 16 & 18 & 16 & 21 & 67 & 10 \\
\hline Mo & 1.5 & (4.5) & 1.3 & - & 4.9 & 3.9 & 410 & 1.5 \\
\hline P & 440 & (1330) & 675 & 430 & 250 & 460 & 1140 & 360 \\
\hline \multicolumn{9}{|l|}{ No. of } \\
\hline Samples & 90 & & 11 & 9 & 88 & 58 & 13 & 11 \\
\hline
\end{tabular}

ate component of the pelagic sediment is being removed by dissolution as the Mn oxides are being precipitated.

\section{Isotope Studies}

The $\mathrm{Pb}$ isotopic composition of one Mn-oxide crust sample is slightly less radiogenic than seawater, whereas another sample shows a considerable component of basaltic $\mathrm{Pb}$ (Barrett, et al., this vol.). A sample of $\mathrm{Mn}$ $\mathrm{Fe}$ oxide mud has the composition of average Mn nodule. This strengthens the interpretation made on the basis of rare-earth element (REE) data that this sample has formed under the influence of completely normal seawater.

Limited data on two Mn-oxide crust samples and the $\mathrm{Mn}-\mathrm{Fe}$ oxide mud sample suggest a negative correlation between $\delta^{18} \mathrm{O}$ and $\delta \mathrm{D}$. In a plot of $\mathrm{Fe}+\mathrm{Mn}$ versus $\delta^{18} \mathrm{O}$, the two Mn-oxide crusts and the Mn-Fe oxide mud sample plot near or on extrapolations of the tie-lines between authigenic Mn nodules and authigenic silicates (phillipsite) (Fig. 3). Since these authigenic phases have formed in oxygen isotopic equilibrium with bottom seawater having a temperature of about $2^{\circ} \mathrm{C}$ (Savin and Epstein, 1970; Dymond et al., 1973), it can be inferred that the Leg 70 manganiferous sediment has formed under similar conditions.

\section{Nontronitic Clay}

The overwhelming majority of recovered hydrothermal sediment is composed of nontronite. Megascopically, the nontronite is green to greenish black and forms semiconsolidated angular aggregates ranging from less than $1 \mathrm{~mm}$ to $20 \mathrm{~mm}$ in size. Occasional yellowish to brownish orange patinas suggest local oxidizing conditions with depth in the mounds. Aggregates can readily be crushed between the fingers. Smear slides made after

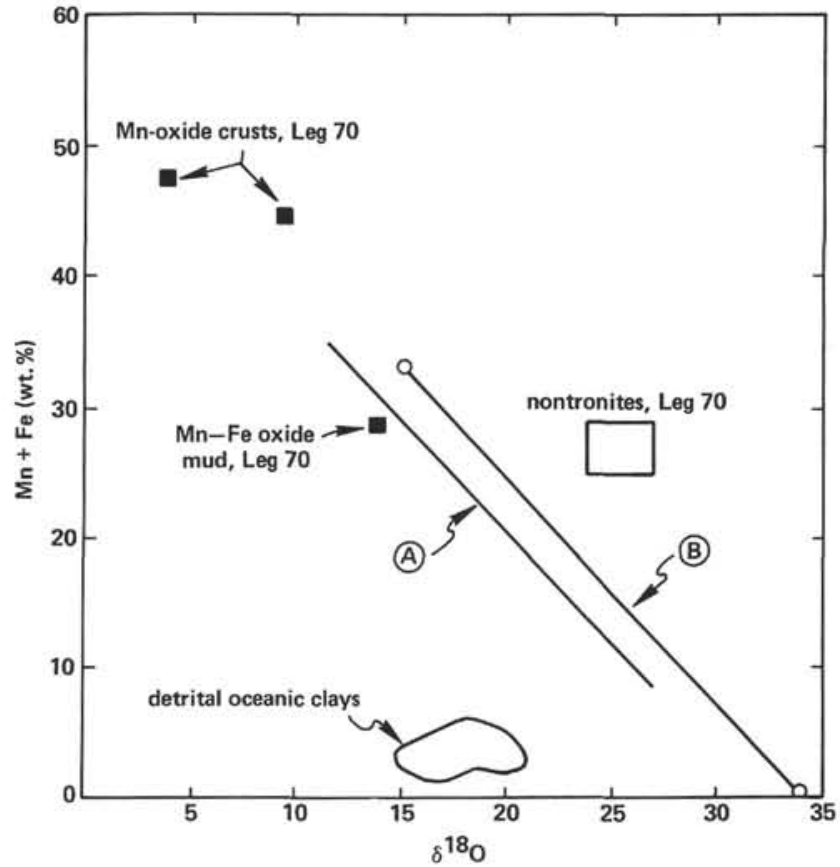

Figure 3. Plot of $\mathrm{Fe}+\mathrm{Mn}$ vs. $\delta^{18} \mathrm{O}$ for some metalliferous sediments from the Galapagos mounds. (From Barrett, Friedrichsen, Fleet, this volume. See caption to Fig. 4 of that article for full explanation.)

crushing the aggregates yield fine silt- to sand-sized, sub-equant to irregular-shaped grains. Impregnated thin sections of nontronitic material reveal fine-grained aggregates with lamella, vermiform, and concentric or spherulitic grain textures. Well-formed authigenic grains with overgrowths are also present (Borella et al., this volume). These features are consistent with the forma- 
tion of some nontronite as a primary, void-filling precipitate.

Thin-section evidence also indicates that nontronite replaces calcareous and siliceous microfossils. Replaced and partially dissolved microfossils are most common in the transitional zones of finer-grained, more compact nontronite which exist between pelagic and coarse granular hydrothermal layers (Borella et al., this volume). In the interiors of the green hydrothermal layers, recognizable replaced microfossils become very sparse. However, the presence of partially to completely nontronitic fecal pellets in many thin sections from all depths in the mounds and in nontronitic mottles in the off-mounds sites is evidence suggesting hydrothermal replacement of pelagic sediment (Borella et al., this volume). Thus, it appears that nontronite forms both as a primary precipitate from hydrothermal pore waters (forming authigenic grains and overgrowths, and filling microfossil tests) and as a replacement of microfossil tests and fecal pellets.

Honnorez et al. (this volume) and Varentsov et al. (this volume) describe Leg 70 nontronites as a mixedlayer celadorite-nontronite (i.e., both micaceous and smectitic layers are present). Structural formulas calculated for this mineral are given in Table 3 for several samples from Hole 509B, for example. Honnorez et al. and Varentsov et al. (this volume) also found that in Holes 509B, 506, and 506C the proportion of celadonite was greater $(70-90 \%)$ in the lower hydrothermal units than in the upper units. In Hole 509B, the K content of the hydrothermal smectites also increases with depth (Fig. 4) (Migdisov et al., this volume).

The age of the nontronites that we drilled, based on uranium isotopes (Lalou et al., this volume), ranges from 90,000 to 300,000 years. Uranium isotopes further suggest that the nontronites form as a result of the interaction of hydrothermal solution with pelagic oozes, rather than from hydrothermal solutions alone.

Chemical data on nontronite material from the mounds area have been previously reported by Corliss et al. (1978) for dredged material, and by Hekinian et al.
(1978), Schrader et al. (1980), Dymond et al. (1980) and Rateev et al. (1980) for samples recovered by rotary drilling in Leg 54. Selected chemical data for Leg 70 nontronites are given in Tables 2 and 4. Additional data on major elements are given in Honnorez et al. (this volume), Barrett et al. (this volume), and Varentsov et al. (this volume).

The main features characterizing the composition of the nontronite are two: (1) its near constancy from site to site or from one hydrothermal layer to another at a particular site, and (2) relative to the carbonate-free fraction of normal pelagic oozes, its significant depletion in $\mathrm{Ca}, \mathrm{Al}, \mathrm{Mn}, \mathrm{Li}, \mathrm{Be}, \mathrm{Sr}, \mathrm{Ti}, \mathrm{V}, \mathrm{Cr}, \mathrm{Co}, \mathrm{Ni}, \mathrm{Cu}$, $\mathrm{Zn}, \mathrm{Pb}$, and $\mathrm{P}$ and enrichment in $\mathrm{K}$ and $\mathrm{Fe}\left(\mathrm{Mg}, \mathrm{SiO}_{2}\right.$, and Mo are neither enriched nor depleted). The generally low content in trace metals and lack of significant correlations of minor metals with $\mathrm{Fe}$ implies that the nontronites are very pure precipitates and that the trace elements are incorporated within impurities rather than within the nontronite itself (Moorby and Cronan, this volume).

Electron microprobe analyses of individual well-consolidated granules indicate that granules have a nearconstant major element composition regardless of the mound site or stratigraphic position within the mound (Barrett et al., this volume). Moorby and Cronan (this volume) found that fewer than $10 \%$ of the total $\mathrm{Fe}$ in nontronites was in the $\mathrm{Fe}^{2+}$ state, in agreement with earlier findings (Donnelly, 1980).

The total concentration of REE's in hydrothermal sediments (nontronites and Mn-oxide crusts below the surface oxidized layer) is generally $<10 \mathrm{ppm}$, i.e., up to an order of magnitude less than their average content in carbonate-free pelagic oozes (cf. Table 4). However, the REE distribution patterns in the hydrothermal sediments and pelagic oozes are much the same (Migdisov et al., this volume). In particular, the patterns all have a moderately negative Ce anomaly, reflecting the role of seawater in determining the REE pattern (Bender et al., 1971; Piper, 1973). Some nontronites, however, have

Table 3. Structural and crystallographic data for the hydrothermal green nontronitic material from Hole 509B, Leg 70, as determined by X-ray dif fraction (from Varentsov et al., this volume).

\begin{tabular}{|c|c|c|c|c|c|c|c|c|}
\hline \multirow[b]{2}{*}{ No. } & \multirow{2}{*}{$\begin{array}{c}\text { Sample } \\
\text { (interval in } \mathrm{cm} \text { ) }\end{array}$} & \multirow[b]{2}{*}{$W_{m}: W_{s}$} & \multirow{2}{*}{$\begin{array}{l}\text { Structural Formula } \\
\text { to } \mathrm{O}_{10}(\mathrm{OH})_{2}\end{array}$} & \multicolumn{2}{|c|}{ Charge } & \multirow{2}{*}{$\begin{array}{c}d(001) \\
(\overline{\mathrm{A}})\end{array}$} & \multirow{2}{*}{$\begin{array}{c}d(060) \\
(\AA)\end{array}$} & \multirow{2}{*}{$\stackrel{b}{(\dot{A})}$} \\
\hline & & & & Tetrahedron & Octahedron & & & \\
\hline 1 & $2-1,52-54$ & $0.60: 0.40$ & $\left(\mathrm{Si}_{3.81} \mathrm{Al}_{0.05} \mathrm{Fe}_{0.14}^{3+}\right)\left(\mathrm{Fe}_{1.73}^{3} \mathrm{Mg}_{0.27}\right) \mathrm{Mg}_{0.12} \mathrm{~K}_{0.23}$ & 0.19 & 0.27 & 12.0 & 1.5163 & 9.098 \\
\hline 2 & $2-2,57-59$ & $0.50: 0.50$ & $\left(\mathrm{Si}_{3.80} \mathrm{Al}_{0.06} \mathrm{Fe}_{0.14}^{3+}\right)\left(\mathrm{Fe}_{1.72}^{3+} \mathrm{Mg}_{0.28}\right) \mathrm{Mg}_{0.13} \mathrm{~K}_{0.16} \mathrm{Ca}_{0.03}$ & 0.20 & 0.28 & 12.3 & 1.5166 & 9.100 \\
\hline \multicolumn{2}{|c|}{ Average: Nos. 1,2} & $0.55: 0.45$ & $\left(\mathrm{Si}_{3.80} \mathrm{Al}_{0.06} \mathrm{Fe}_{0.14}^{3+}\right)\left(\mathrm{Fe}_{1.73}^{3} \mathrm{Mg}_{0.27}\right) \mathrm{Mg}_{0.13} \mathrm{~K}_{0.21}$ & 0.20 & 0.27 & - & - & - \\
\hline 3 & $3-3,27-29$ & $0.75: 0.25$ & $\left(\mathrm{Si}_{3.84} \mathrm{Al}_{0.05} \mathrm{Fe}_{0.11}^{3+}\right)\left(\mathrm{Fe}_{1.63}^{3}{ }^{+} \mathrm{Mg}_{0.37}\right) \mathrm{Mg}_{0.07} \mathrm{~K}_{0.36} \mathrm{Ca}_{0.02}$ & 0.16 & 0.37 & 10.9 & 1.5146 & 9.088 \\
\hline 4 & $4-1,104-105$ & $0.80: 0.20$ & $\left(\mathrm{Si}_{3.85} \mathrm{Al}_{0.03} \mathrm{Fe}_{0.12}^{+}\right)\left(\mathrm{Fe}_{1.63}^{3+} \mathrm{Mg}_{0.37}\right) \mathrm{Mg}_{0.07} \mathrm{~K}_{0.37}$ & 0.15 & 0.37 & 10.7 & 1.5148 & 9.089 \\
\hline 5 & $4-2,23-25$ & $0.70: 0.30$ & $\left(\mathrm{Si}_{3.88} \mathrm{Al}_{0.06} \mathrm{Fe}_{0.06}^{+}\right)\left(\mathrm{Fe}_{1.64}^{3}{ }^{+} \mathrm{Mg}_{0.36}\right) \mathrm{Mg}_{0.09} \mathrm{~K}_{0.29}$ & 0.12 & 0.36 & 11.2 & 1.5144 & 9.086 \\
\hline \multicolumn{2}{|c|}{ Average: Nos. $3,4,5$} & $0.75: 0.25$ & $\left(\mathrm{Si}_{3.86} \mathrm{Al}_{0.05} \mathrm{Fe}_{0.09}^{+}\right)\left(\mathrm{Fe}_{1.63}^{3+} \mathrm{Mg}_{0.37}\right) \mathrm{Mg}_{0.09} \mathrm{~K}_{0.33}$ & 0.14 & 0.37 & - & - & - \\
\hline \multicolumn{2}{|c|}{$\begin{array}{l}\text { Structural formula } \\
\text { for mica component } \\
\text { (celadonite) }\end{array}$} & $1: 0$ & {$\left[\mathrm{Si}_{3.95}\left(\mathrm{Al}, \mathrm{Fe}^{3+}\right)_{0.05}\right]\left(\mathrm{Fe}_{1.60}^{3+} \mathrm{Mg}_{0.40}\right) \mathrm{K}_{0.45}$} & 0.05 & 0.40 & - & - & - \\
\hline \multicolumn{2}{|c|}{$\begin{array}{l}\text { Structural formula for } \\
\text { smectite component } \\
\text { (nontronite) }\end{array}$} & $0: 1$ & {$\left[\mathrm{Si}_{3.60}\left(\mathrm{Al}, \mathrm{Fe}^{3+}\right) 0.40\right]\left(\mathrm{Fe}_{1.80}^{3+} \mathrm{Mg}_{0.20}\right) \mathrm{Mg}_{0.30}$} & 0.40 & 0.20 & - & - & - \\
\hline
\end{tabular}




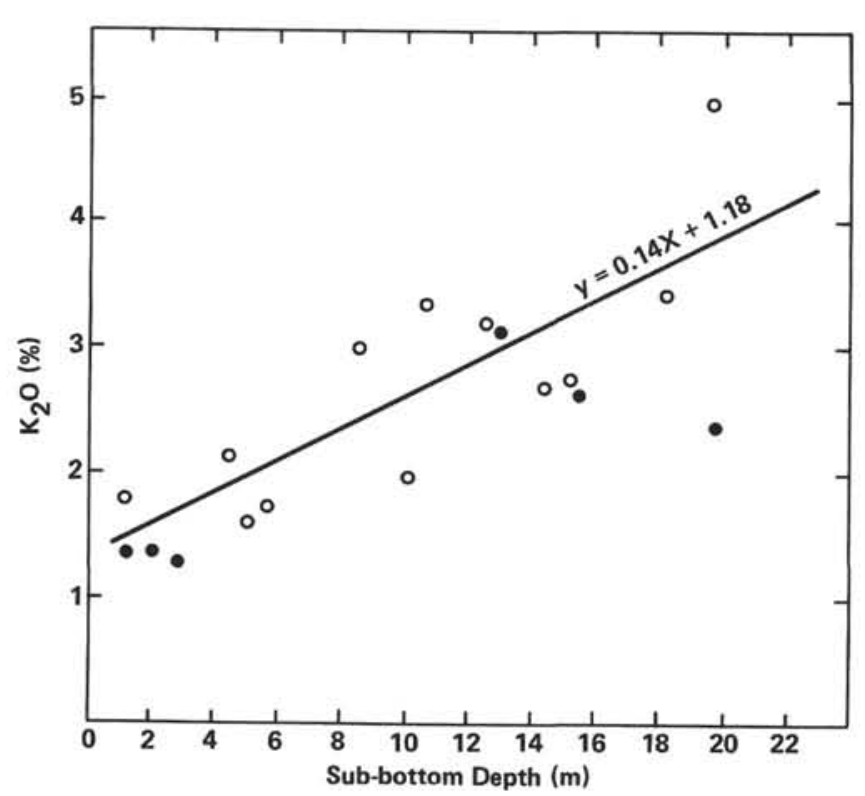

Figure 4. $\mathrm{K}_{2} \mathrm{O}$ content of hydrothermal green nontronite material versus sub-bottom depth in two mounds sections (From Migdisov, Gradusov, et al., this volume). (Open circles: Hole 509B; solid circles: Hole 507D.)
REE concentrations up to two orders of magnitude less than the carbonate-free oozes. In these cases, the nontronites are characterized by REE patterns (Varentsov et al., this volume) which are similar to basalt REE distribution patterns and are close to patterns of vein smectites from basalt alteration zones in the lower part of Hole 504B, Costa Rica Rift (Sharaskin et al., in prep., Site 504B volume). Varentsov et al. (this volume) interpret such patterns as reflecting precipitation from hydrothermal solutions which have circulated through basaltic crust.

Courtois (1981), in a study of REE's in hydrothermal sediments recovered by Leg 54 from the mounds area, interpreted the low REE concentrations and slightly negative $\mathrm{Ce}$ anomalies as resulting from a possible combination of basement-derived solutions, carrying a basaltic REE pattern, and normal seawater. Barrett et al. (this volume), in a more limited study, found that most granular nontronites contained a total of less than several ppm of REE's. However, two samples contained higher REE concentrations and displayed seawater-type patterns, although with only moderately negative $\mathrm{Ce}$ anomalies. A sample of $\mathrm{Mn}-\mathrm{Fe}$ oxide mud, from near the top of Hole 509B, yielded a seawater REE pattern,

Table 4. Average composition of hydrothermal sediments and pelagic sediments, on a carbonate-free basis and according to depth within the mound (Hole 509B). Data for the off-mound hole (509) are also given (from Migdisov et al., this volume).

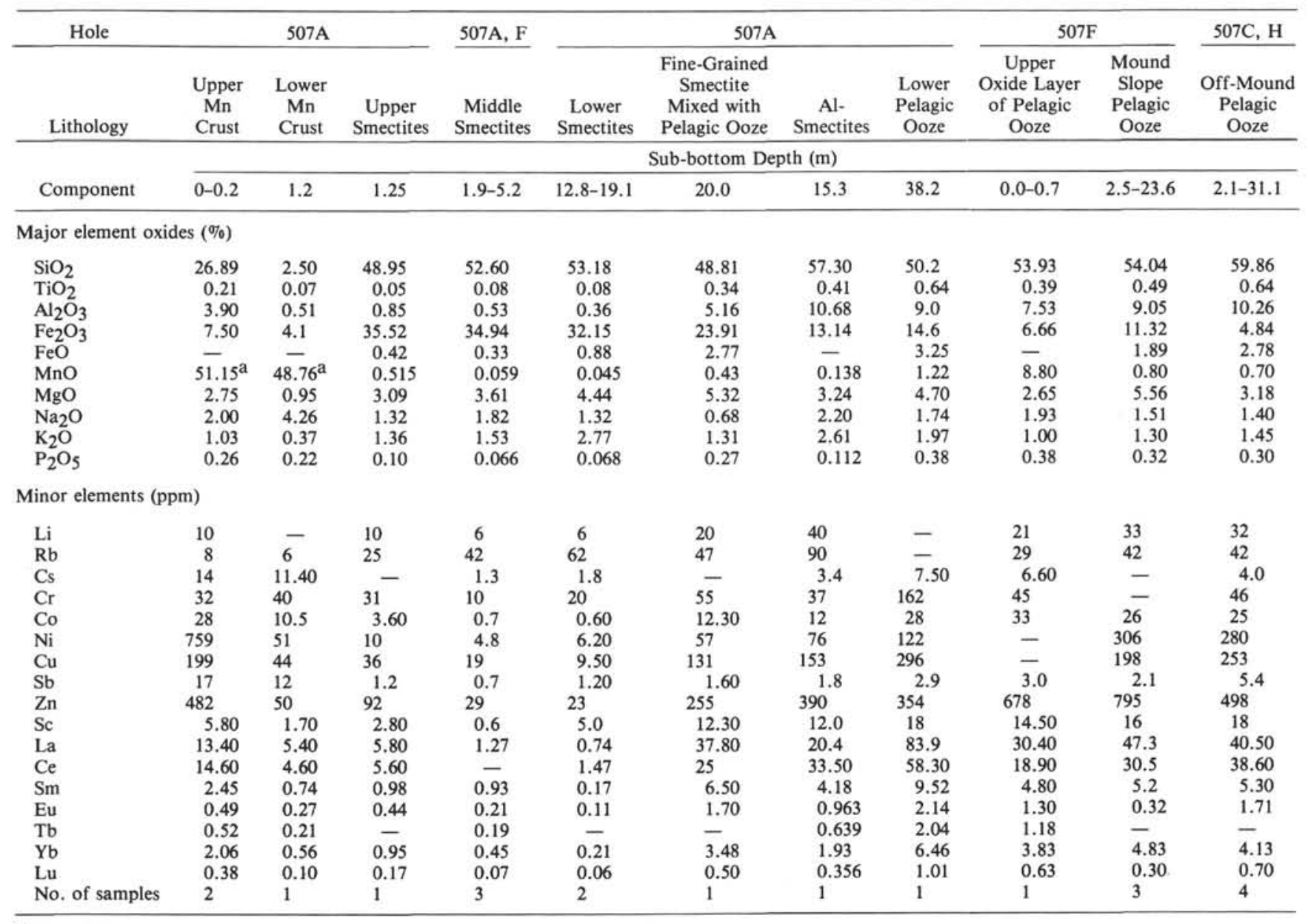

${ }^{a} \mathrm{Mn}$ as $\mathrm{MnO}_{2}$. 
with both the pattern and the element abundances very similar to metalliferous samples from the East Pacific Rise. Hence, this sample (which is of an unusual lithology) has formed entirely under the influence of seawater, possibly by direct discharge of solutions into bottom waters.

\section{Isotope Studies}

Barrett (this volume) found that the $\mathrm{Pb}$ isotopic composition of nontronites from the mounds area defined approximately linear arrays in conventional isotopic plots. The more radiogenic ends of these arrays are directed towards and closely approach the composition of average Mn nodules, which is considered representative of the $\mathrm{Pb}$ isotopic composition of seawater (Chou and Patterson, 1962). The less radiogenic ends of the arrays overlap with basalt arrays and from several shallow holes in the Galapagos mounds area. The $\mathrm{Pb}$ isotopic composition of the nontronites can therefore be interpreted as the result of mixing of $\mathrm{Pb}$ derived from basaltic (cf. Bender et al., 1971) and seawater sources in varying proportions. The average proportion of basaltic to normal seawater $\mathrm{Pb}$ in the sediment pore waters over the period of nontronite formation would determine where the nontronitic $\mathrm{Pb}$ plots on a mixing line.

A few nontronite samples, however, yielded very unusual, highly radiogenic $\mathrm{Pb}$ isotopic concentrations. These samples, from about the same depth at two different mounds sites (Holes 507F and 509B), are too radiogenic to contain $\mathrm{Pb}$ derived from either typical midocean ridge basalts or seawater (see discussion in Barrett, this volume). The analysis of several of the sediment samples for ${ }^{87} \mathrm{Sr} /{ }^{86} \mathrm{Sr}$ composition indicates that seawater provides virtually all of their strontium (Barrett, this volume).

The $\delta^{18} \mathrm{O}$ and $\delta \mathrm{D}$ values of nontronites show a relatively restricted range of values, the former varying from 24.2 to $26.9 \%$, and the latter from -119 to $-139 \%$ (Table 5) (Barrett and Friedrichsen, this volume). In a plot of $\delta^{18} \mathrm{O}$ versus $\delta \mathrm{D}$, the nontronites occupy a field distinctly different from detrital oceanic clays (Savin and Epstein, 1970). Nontronites display no apparent covariation between $\delta^{18} \mathrm{O}$ and $\delta \mathrm{D}$.

Estimates of the temperatures of formation of the nontronites have been made using their O-isotopic composition and applying the formula of Yeh and Savin (1977) for smectites $\left(1000 \ln \alpha=\left(2.6710^{6} \mathrm{~T}^{-2}\right)-4.82\right)$. This assumes that the higher $\mathrm{Fe}$ contents of nontronite relative to other authigenic marine smectites does not affect fractionations (G. M. McMurtry and H.-W. Yeh, pers. comm., 1981), and that the $\delta^{18} \mathrm{O}$ values from which the nontronites formed was $0.0 \%$, the value for normal seawater. The formation temperatures calculated by this method are relatively low, ranging from about 19 to $30^{\circ} \mathrm{C}$ for granular nontronites and 30 to $32^{\circ} \mathrm{C}$ for a layer of transitional nontronitic mud. The values are similar to the minimum temperature values of about $30^{\circ} \mathrm{C}$ calculated by McMurtry and Yeh (1981) for three authigenic Fe-rich montmorillonites from surface metalliferous sediment on the crest of the East Pacific Rise and adjacent Bauer Basin (one value of $2^{\circ} \mathrm{C}$ was also recorded).
Table 5. Oxygen and hydrogen isotopic composition of metalliferous and pelagic sediments from the Galapagos mound area, Leg 70 . Also given are nontronite formation temperatures, as estimated from their oxygen isotopic values (from Barrett, Friedrichsen, Fleet, this volume).

\begin{tabular}{rllrrr}
\hline $\begin{array}{c}\text { Sample } \\
\text { (No.) }\end{array}$ & $\begin{array}{c}\text { Sample } \\
\text { (interval in cm) }\end{array}$ & \multicolumn{1}{c}{ Lithology } & $\delta^{18} \mathrm{O}$ & \multicolumn{1}{c}{$\delta \mathrm{D}$} & $\begin{array}{c}\mathrm{T} \\
\left({ }^{\circ} \mathrm{C}\right)\end{array}$ \\
\hline 1 & $506-2-2,69-71$ & Nontronite & 25.9 & -135 & 23 \\
2 & $506-2-2,132-134$ & Nontronite & 25.3 & -124 & 26 \\
3 & $506-4-2,45-47$ & Nontronite & 26.5 & -120 & 21 \\
12 & $506-6-3,39-41$ & Nontronite fraction & 26.0 & - & 23 \\
16 & $506 \mathrm{C}-4-2,74-76$ & Nontronite & 24.9 & -136 & 28 \\
4 & $507 \mathrm{D}-2-1,52-54$ & Nontronite & 24.6 & -122 & 30 \\
5 & $507 \mathrm{~F}-2-2,11-13$ & Nontronite & 26.9 & -133 & 19 \\
6 & $509 \mathrm{~B}-2-1,44-48$ & Nontronite & 26.7 & -124 & 20 \\
7 & $509 \mathrm{~B}-2-2,52-54$ & Nontronite & 26.2 & -138 & 22 \\
17 & $509 \mathrm{~B}-3-2,53-55$ & Trans. nontronite & 24.6 & - & 30 \\
8 & $509 \mathrm{~B}-3-2,60-61$ & Trans. nontronite & 24.2 & -124 & 32 \\
9 & $509 \mathrm{~B}-4-3,37-39$ & Nontronite & 26.7 & -128 & 20 \\
10 & $509 \mathrm{~B}-1-2,85-90$ & Mn-oxide crust & 3.7 & -175 & \\
11 & $509 \mathrm{~B}-2-1,114-118$ & Mn-Fe-oxide mud & 13.8 & -138 & \\
18 & $506 \mathrm{C}-2-1,67-69$ & Mn-oxide crust & 9.4 & -157 & \\
12 & $506-6-3,39-41$ & Pelagic ooze fraction & 31.8 & -106 & \\
13 & $506-8-1,86-88$ & Pelagic ooze & 32.3 & -91 & \\
14 & $506 \mathrm{~B}-2-3,12-14$ & Pelagic ooze & 31.7 & -99 & \\
15 & $506 \mathrm{~B}-5-1,94-96$ & Pelagic ooze & 32.6 & -105 & \\
\hline
\end{tabular}

Note: The $\delta^{18} \mathrm{O}$ values of Samples $12,13,14$, and 15 are for the carbonate fraction of the ooze (typically about $80 \%$ ). The $\delta^{13} \mathrm{C}$ values for these fractions are $1.5,1.8,0.6$, and 1.9 , respectively.

\section{Transitional Nontronitic Clay}

The compact pale green sediment which typically occurs between granular nontronite and pelagic ooze horizons was not reported from Leg 54, very probably because of extensive sediment disturbance caused by the rotary drilling. The average composition of the transitional nontronite recalculated on a carbonate-free basis (Table 6) (after Moorby and Cronan, this vol.) is intermediate between that of pelagic ooze (on a carbonatefree basis) and pure nontronite (Table 2), suggesting that the transitional sediment is a mixture of somewhat variable proportions of these two sediment types. As noted

Table 6. Average composition of transitional sediments from each hole sampled on Leg 70 (from Moorby and Cronan, this volume).

\begin{tabular}{cccccccc}
\hline \multicolumn{9}{c}{ Hole } & & All Sites & $\begin{array}{c}\text { Pelagic } \\
\text { Sediments } \\
\text { Element }\end{array}$ & $\begin{array}{c}506 \\
(n=22)\end{array}$ & $\begin{array}{c}506 \mathrm{C} \\
(n=8)\end{array}$ & $\begin{array}{c}507 \mathrm{D} \\
(n=14)\end{array}$ & $\begin{array}{c}507 \mathrm{~F} \\
(n=4)\end{array}$ & $\begin{array}{c}509 \mathrm{~B} \\
(\mathrm{CF})\end{array}$ & $\begin{array}{c}(\mathrm{CF}) \\
(n=58)\end{array}$ & $(n=90)$ \\
\hline
\end{tabular}

\begin{tabular}{lccccccc}
\hline & \multicolumn{7}{c}{$(\%)$} \\
$\mathrm{K}$ & 1.1 & 1.4 & 0.93 & 0.73 & 1.1 & 1.2 & 0.8 \\
$\mathrm{Mg}$ & 2.0 & 2.2 & 2.0 & 2.3 & 2.1 & 2.4 & 2.1 \\
$\mathrm{Ca}$ & 7.2 & 2.6 & 7.0 & 0.8 & 3.4 & 5.4 & 27 \\
$\mathrm{Al}$ & 2.1 & 2.5 & 1.9 & 3.3 & 1.9 & 2.5 & 3.7 \\
$\mathrm{SiO}$ & 33.7 & 37.1 & 37.9 & 37.8 & 35.7 & 41.0 & 44.9 \\
$\mathrm{Mn}$ & 0.22 & 0.35 & 0.08 & 0.09 & 0.20 & 0.22 & 0.8 \\
$\mathrm{Fe}$ & 9.4 & 10.0 & 9.7 & 9.7 & 11.8 & 11.4 & 3.8 \\
& & & & $(\mathbf{p p m})$ & & & \\
& & & & & & & \\
$\mathrm{Li}$ & 21 & 18 & 21 & 35 & 17 & 24 & 25 \\
$\mathrm{Sr}$ & 400 & 360 & 160 & 133 & 380 & 350 & 2900 \\
$\mathrm{P}$ & 470 & 470 & 410 & 620 & 430 & 530 & 1330 \\
$\mathrm{Ti}$ & 970 & 1100 & 850 & 1500 & 910 & 1130 & 1730 \\
$\mathrm{~V}$ & 100 & 75 & 84 & 160 & 86 & 109 & 200 \\
$\mathrm{Cr}$ & 43 & 53 & 47 & 56 & 45 & 54 & 91 \\
$\mathrm{Co}$ & 11 & 11 & 8 & 12 & 7 & 11 & 27 \\
$\mathrm{Ni}$ & 110 & 75 & 43 & 90 & 50 & 88 & 260 \\
$\mathrm{Cu}$ & 150 & 120 & 93 & 130 & 84 & 135 & 254 \\
$\mathrm{Zn}$ & 180 & 150 & 160 & 270 & 150 & 195 & 424 \\
$\mathrm{~Pb}$ & 21 & 33 & 14 & 24 & 17 & 24 & 52 \\
\hline
\end{tabular}

Note: CFB $=$ carbonate-free basis; $n=$ no. of samples analyzed. 
by Varentsov et al. (this volume), some dissolution of the pelagic component of the transitional sediment appears to have occurred, as evidenced by the decrease in the bulk $\mathrm{CaCO}_{3}$ content and $\mathrm{Fe} /(\mathrm{Fe}+\mathrm{Mg}+\mathrm{Al})$ ratio, and the occurrence of an admixture of feldspar, quartz, and zeolite phases.

\section{Pelagic Sediments}

\section{Foraminifer-Nannofossil Oozes}

Pelagic sediments began to accumulate approximately 600,000 years ago and dominated to 300,000 years ago (Lalou et al., this volume). From 300,000 years to the present, hydrothermal activity has dominated under a rain of pelagic sediment.

The pelagic oozes encountered at all sites drilled are primarily calcareous nannofossil oozes with varying amounts of foraminifers, diatoms, radiolarians, and silicoflagellates. The dominant colors are light greenish gray, greenish gray, and light olive gray. The majority of pelagic oozes are highly bioturbated, which has obliterated most of any original internal bedding and lamination (Borella et al., this volume). Preservation of biogenic sedimentary structures is excellent, with numerous examples of Zoophycus, halo burrows, and circular Planolites(?) observed throughout the cores. Dark mottles in mounds and off-mounds sites contain fine-grained nontronite or Fe-sulfide admixtures and probably represent burrows which have been affected by throughflowing, relatively reduced hydrothermal solutions.

Minor amounts of volcanic ash $(<2 \%)$ are present as dispersed shards in some pelagic oozes. Discrete layers of ash, consisting almost entirely of acidic glass, were observed in only three cases, Sections 507D-3-2, 509-42, and 509B-2-3 (at approximate depths of 6.5, 12.0, and $6.3 \mathrm{~m}$, respectively). More ash layers may have existed originally, but been subsequently destroyed by the extensive burrowing activity, or, in the case of the mounds sites, by possible replacement with nontronitic material.

Smear slide observations indicate that preservation of microfossils is better in the nonmounds $(508,510)$ and off-mounds sites than on the mounds. It was also found that the abundance of siliceous microfossils decreases more rapidly with depth on the mounds, as compared to the adjacent off-mounds sites (Fig. 2). Since the distance between mounds and off-mounds sites is not more than several tens of meters, changes in planktonic productivity and dissolution compensation depth can be ruled out as causes for the variation in siliceous microfossil abundance. It is probable that the upwelling hydrothermal solutions associated with mounds formation corrode microfossils more thoroughly, and to a higher level in the stratigraphic column, than on off-mounds sites.

The clay component within the pelagic sediments in the mounds area is significantly different in composition from the hydrothermal nontronite clays. The clays contain notably less $\mathrm{Fe}$ and more $\mathrm{Al}$ and can be described as variably ferruginous smectites (Varentsov et al., this volume).
The average composition of the pelagic sediments (Table 2) given by Moorby and Cronan (this volume) and by Migdisov et al. (this volume) compares well with data for pelagic sediments recovered from Leg 54 (Dymond et al., 1979; Schrader et al., 1980). In Leg 70 sediments, however, it was found that surface and nearsurface sediment had a $\mathrm{SiO}_{2}$ to $\mathrm{CaCO}_{3}$ ratio of about 1 to 5 , but with increasing depth the biogenic silica content falls to near zero. The decrease appears to occur over a fairly narrow depth interval-shallower in mounds holes than in off-mounds and nonmounds holes as discussed above. Moorby and Cronan (this volume) also note that Mn content of pelagic sediments shows some variation from hole to hole. Varentsov et al. (this volume) report that $\mathrm{Mn} / \mathrm{Fe}, \mathrm{Ba} / \mathrm{Ti}$, and $\mathrm{Ba} / \mathrm{Sr}$ ratios in the pelagic sediments, in particular the $\mathrm{Ba} / \mathrm{Ti}$ ratio, are significantly higher than in typical deep sea carbonate sediments (Turekian and Wedepohl, 1961). They interpret this as reflecting the existence of some hydrothermal activity during carbonate ooze sedimentation.

Moorby and Cronan (this volume) analyzed samples of pelagic ooze from immediately overlying basement in nine holes. They found that while the nine samples showed some variations, there is no significant difference in the composition of basal sediments from the different hole types (i.e., mounds, off-mounds, nonmounds). Three holes $(506,507 \mathrm{~F}$, and 509B) showed some local enrichment in $\mathrm{Fe}$, but even in these samples $\mathrm{Fe}, \mathrm{Mn}, \mathrm{Ca}, \mathrm{Ni}$, and $\mathrm{Zn}$ are much lower, and $\mathrm{Al}$ and $\mathrm{Ti}$ much higher, than in typical basal metalliferous sediments from the East Pacific Rise. The composition of the basal Leg 70 sediments is interpreted by Moorby and Cronan (this volume) as resulting in most cases from a mixture of biogenic, basaltic, and terrigenous material, although Sites 506 and 507 show some metalliferous component. This is in some conflict with the conclusions of Dymond et al. (1979), who analyzed basal sediment from Leg 54 holes and found similarities between this material and basal metalliferous material from $6^{\circ} \mathrm{S}$ on the East Pacific Rise.

\section{Oxidized Surface Ooze}

The mudline in every core is marked by a grayish brown to moderate brown pelagic ooze about 10 to 50 $\mathrm{cm}$ thick. Such sediments are typical of the region in general (Bonatti et al., 1971) and were encountered by Leg 54 in the mounds area (Dymond et al., 1980). This sediment contains a higher proportion of siliceous and lower proportion of calcareous microfossils than do the underlying foraminifer-nannofossil oozes. The contact between the brown oozes and the underlying greenish gray, more calcareous oozes is sharp. The brownish oozes contain a higher proportion (up to $2 \%$ ) of Mn microaggregates relative to the calcareous oozes. This, together with some probable Fe oxides, has produced the dark color. The lower proportion of calcareous sediment in the surface layer suggests a recent change in carbonate accumulation rates. As discussed by Borella (this volume), this change may reflect decreased surface productivity or increased sediment dissolution associated with the present interglacial stage. Several other brown "oxidized" 
layers interpreted as "relict" surface layers are observed at depth within some cores and may reflect earlier decreases in carbonate accumulation rates in response to climatic changes (Borella, this volume). Some of these "relict" surface layers (e.g., $7 \mathrm{~m}$ sub-bottom) can be correlated from hole to hole and may represent changes in the physical properties of the sediments.

The uppermost 10 to $50 \mathrm{~cm}$ of surface sediment. oxidized to a brownish color, is enriched in $\mathrm{Mn}, \mathrm{Ni}, \mathrm{Cu}$, $\mathrm{Zn}$, and $\mathrm{P}$ compared to the underlying sediment (Table 2) (Moorby and Cronan, this volume). The Mn enrichment results from its diagenetic remobilization and reprecipitation near the sediment surface (Lynn and Bonatti, 1965). Selective chemical leaching of the samples indicates that the other enriched elements are associated with the Mn phase (Varnavas et al., this volume).

\section{Pore-Water Chemistry}

Our pore-water results reflect the vertical advection of hydrothermal solutions throughout the mounds area. (Bender, this volume.) Shipboard pore-water sampling on cores was done at in situ temperatures, using a Sorvall refrigerated super-speed centrifuge. Comparison with seven in situ pore-water samples showed that the $\mathrm{Mg}$ and $\mathrm{Si}$ concentrations of the centrifuged samples are close to in situ values, while $\mathrm{Ca}$ concentrations are 0.4 $\mathrm{mM}$ less than in situ values. The comparison omits two Site 508 in situ samples, which are believed to differ in composition from the centrifuged samples as a result of local variability in pore-water chemistry rather than as a sampling artifact. Suboxic squeezing experiments on Leg 70 show that low Si concentrations are not an artifact of $\mathrm{Fe}^{2+}$ oxidation during centrifuging (Loder et al., 1978).

Pore-water chemistry is shown in Figure 5 for three contrasting holes: A low heat-flow site (508), a mounds site (509B), and an off-mounds pelagic site (509). Similar results are found at the other holes in this region. The pore-water chemistry reveals the following features:

1) Pore waters at high heat-flow sites (509 and 509B) are enriched in $\mathrm{Ca}$ by 0.5 to $2.0 \mathrm{mM}$ and depleted in $\mathrm{Mg}$ by 1.5 to $3.0 \mathrm{mM} / 1$ relative to bottom water. At the low heat-flow Site 508, Ca is close to the bottom-water value and $\mathrm{Mg}$ is only slightly depleted (by about $0.6 \mathrm{mM}$ ). However, three of the Site 508 samples, including two in situ samples taken at 19 and 26 meters, show positive $\mathrm{Ca}$ and negative $\mathrm{Mg}$ anomalies comparable to those at high heat-flow sites. The $\mathrm{Ca}$ enrichment and $\mathrm{Mg}$ depletion of pore-water samples from high heat-flow sites probably reflect flow through the sediments of seawater which has gained $\mathrm{Ca}$ and lost $\mathrm{Mg}$ as a result of reaction with basalt. The $\mathrm{Ca}$ and $\mathrm{Mg}$ concentrations of low heat-flow site samples, being respectively similar to or slightly lower than the values for bottom seawater, are thought to correspond to downward flow of seawater and recharge of the basement aquifer (Williams et al., 1974; Green et al., 1981). The positive $\mathrm{Ca}$ and negative $\mathrm{Mg}$ anomalies of pore waters at the bottom of low heat-flow Site 508 may reflect diffusive exchange of $\mathrm{Ca}$ and $\mathrm{Mg}$ out of basalt, superimposed on slow recharge.
2) Si concentrations of pore waters are generally highest in sediments located in low heat-flow regions, reaching $600 \mu \mathrm{M}$. These high $\mathrm{Si}$ concentrations probably reflect dissolution of biogenic silica near the sediment surface, accompanied by downward advection. The lower Si concentration (between 200 and $400 \mu \mathrm{M}$ ) in high heatflow regions is probably associated with pore waters which enter the mounds sediments from below and gain biogenic $\mathrm{Si}$ as they ascend. This low $\mathrm{Si}$ concentration may indicate the presence of Si-depleted formation waters.

3) $\mathrm{NH}_{3}$ concentrations are highest in pore-water samples from low heat-flow sites. They may indicate descent of solutions which pick up $\mathrm{NH}_{3}$ produced by sulfate reduction near the sediment water interface and advect it downward. In contrast, the pore waters from Hole 509 have gained metabolic ammonia as they rise; the ammonia profile reflects production and downward diffusion against slow upwelling. The low ammonia concentrations in the pore water from Hole 509B reflect rapid convection and perhaps a deficiency of organic matter in the authigenic $\mathrm{Mn}$ and $\mathrm{Fe}$ compounds and sediments of the mounds.

\section{Physical Properties}

Wet-bulk density, grain density, porosity, compressional-wave velocity, and thermal conductivity of over 200 sediment samples were measured on board D/V Glomar Challenger. In Table 7, the means and standard deviations of these measurements are given for the four sediment types recovered (Karato and Becker, this volume). Grain densities and, in general, other physical properties systematically covary among these types in the order in which they are listed. An exception is the nongranular green clays, which were the most porous sediment and, as a result, had the lowest wet-bulk densities and thermal conductivities.

The differences among the various sediment properties cause irregular variations in physical properties with depth in holes where both pelagic and hydrothermal sediments were cored (Holes 506, 506C, 506D, 507D, 509B). In contrast, the properties of pelagic sediments, whether or not interbedded with hydrothermal materials, vary smoothly with depth in a linear fashion similar for all holes. There are no obvious contrasts to account for regional seismic reflectors at 7 and 15 meters depth (Lonsdale, 1977), although they may be the result of acoustic interference patterns similar to those found for equatorial Pacific pelagic sediments (Mayer, 1979).

In the thin sediment cover at Sites 506 to 509, the depth gradient of porosity in the pelagic oozes is very high, about -0.2 to $-0.6 \% / \mathrm{m}$ (see Fig. 6). As a result, gradients in wet-bulk density $(0.2$ to $0.6 \% / \mathrm{m})$ and thermal conductivity $(0.5$ to $1 \% / \mathrm{m})$ are also quite high compared to those in thicker pelagic sections (Hamilton, 1976). In Hole 510, with 110 meters of pelagic sediments, the gradients in physical properties are "normal" in the upper section, but near basement (within $30 \mathrm{~m}$ ) they become higher and comparable to those of Sites 506 to 509. The occurrence of these high, near-basement depth 

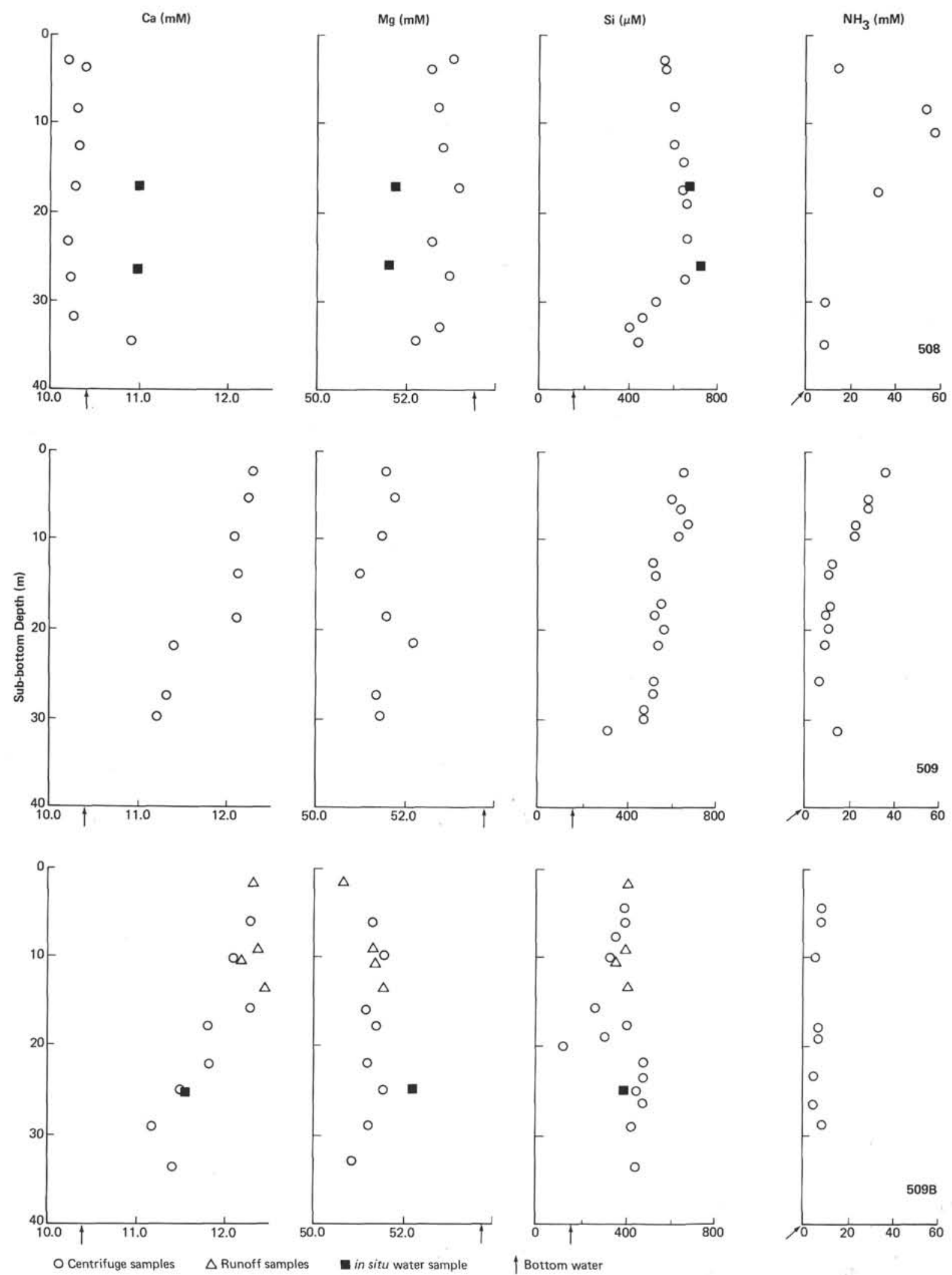

Pore water figure caption: Pore water chemistry of a low heat flow site (508), an off-mound site (509), and a mound hole (5098), Runoff samples were drawn by letting water from nontronite gravels flow into beaker when cores were cut, and filtering the sample through a 0.45 micron filter.

Figure 5. Results of pore-water chemistry analyses of a low heat-flow hole (508), an off-mound hole (509), and a mound hole (509B). Runoff samples were drawn by letting water from nontronite gravels flow into beaker when cores were cut, and filtering the sample through a 0.45 micron filter. (Reprinted from Geol. Soc. Am. Bull., Pt. 1, Vol. 92.) 
Table 7. Average values of physical properties of sediments from the Galapagos area, Leg 70 (from Honnorez, Von Herzen et al., 1980).

\begin{tabular}{lccccc}
\hline & $\begin{array}{c}\text { Wet-bulk } \\
\text { Density } \\
\left(\mathrm{g} / \mathrm{cm}^{3}\right)\end{array}$ & $\begin{array}{c}\text { Grain } \\
\text { Density } \\
\left(\mathrm{g} / \mathrm{cm}^{3}\right)\end{array}$ & $\begin{array}{c}\text { Porosity } \\
(\%)\end{array}$ & $\begin{array}{c}\text { Compressional- } \\
\text { Wave Velocity } \\
(\mathrm{km} / \mathrm{s})\end{array}$ & $\begin{array}{c}\text { Thermal } \\
\text { Conductivity } \\
(\mathrm{W} / \mathrm{mK})\end{array}$ \\
\hline $\begin{array}{c}\text { Manganese } \\
\text { oxides }\end{array}$ & $1.98 \pm 0.26$ & $3.75 \pm 0.36$ & $64.0 \pm 10.3$ & $2.22 \pm 0.07$ & \\
$\begin{array}{c}\text { Granular } \\
\text { green clays }\end{array}$ & $1.46 \pm 0.19$ & $3.13 \pm 0.23$ & $77.9 \pm 8.5$ & $1.61 \pm 0.09$ & $0.80 \pm 0.07$ \\
$\begin{array}{c}\text { Nongranular } \\
\text { green clays }\end{array}$ & $1.20 \pm 0.10$ & $2.74 \pm 0.28$ & $89.8 \pm 5.4$ & $1.55 \pm 0.02$ & $0.78 \pm 0.05$ \\
$\begin{array}{c}\text { Pelagic } \\
\text { sediments }\end{array}$ & $1.32 \pm 0.09$ & $2.65 \pm 0.08$ & $82.2 \pm 4.2$ & $1.51 \pm 0.02$ & $0.91 \pm 0.08$ \\
\hline & & & & & \\
\hline
\end{tabular}

gradients of physical properties in pelagic sediments in every hole cored on Leg 70 suggests that they are related to some regional sediment-basement interaction near the spreading center, as opposed to a more general diagenetic process such as compaction. The preservation of these high gradients in pelagic layers interbedded with hydrothermal deposits implies that the formation of hydrothermal sediments has little effect on the properties of adjacent pelagic sediments.

\section{Paleomagnetism}

A whole-core spinner magnetometer was used on board D/V Glomar Challenger to measure the horizontal component of natural remanent magnetism (NRM) of unsplit HPC sections of sediments recovered at Sites 506, 507, and 509 (Levi, this volume). As expected, no reversals were observed at any of these sites, all of which are younger than the $0.72 \mathrm{~m} . \mathrm{y}$. age assigned to the Brunhes/Matuyama reversal boundary. Whenever lithologic transitions occurred within undisturbed cores, no significant differences were observed between remanence directions and intensities of the pelagic oozes and hydrothermal clays. These preliminary measurements thus suggest either that the deposition of the hydrothermal clays and pelagic oozes was penecontemporaneous, or, if the nontronitic clays were formed later by hydrothermal activity, that the magnetic oxides responsible for the magnetic remanence of the sediments were not significantly altered.

Mn-oxide fragments from Hole 509B exhibit an unusually weak magnetization intensity, $J_{\mathrm{NRM}}$, consistently less than $1 \times 10^{-6}$ gauss $(G)$, which is about an order of magnitude less than that of the nontronitic clays. These low $J_{\text {NRM }}$ values are consistent with the results of DSDP Leg 54, which showed that the Mn-oxide fragments are depleted of iron (Hekinian et al., 1978). However, the relative declinations are surprisingly well clustered, suggesting the presence of a small fraction of a remanence-carrying phase or phases.

\section{COMPARISON WITH OTHER HYDROTHERMAL OCEANIC DEPOSITS}

As noted by Cronan (1980), metal-rich hydrothermal deposits found to date on mid-ocean ridges can be as-

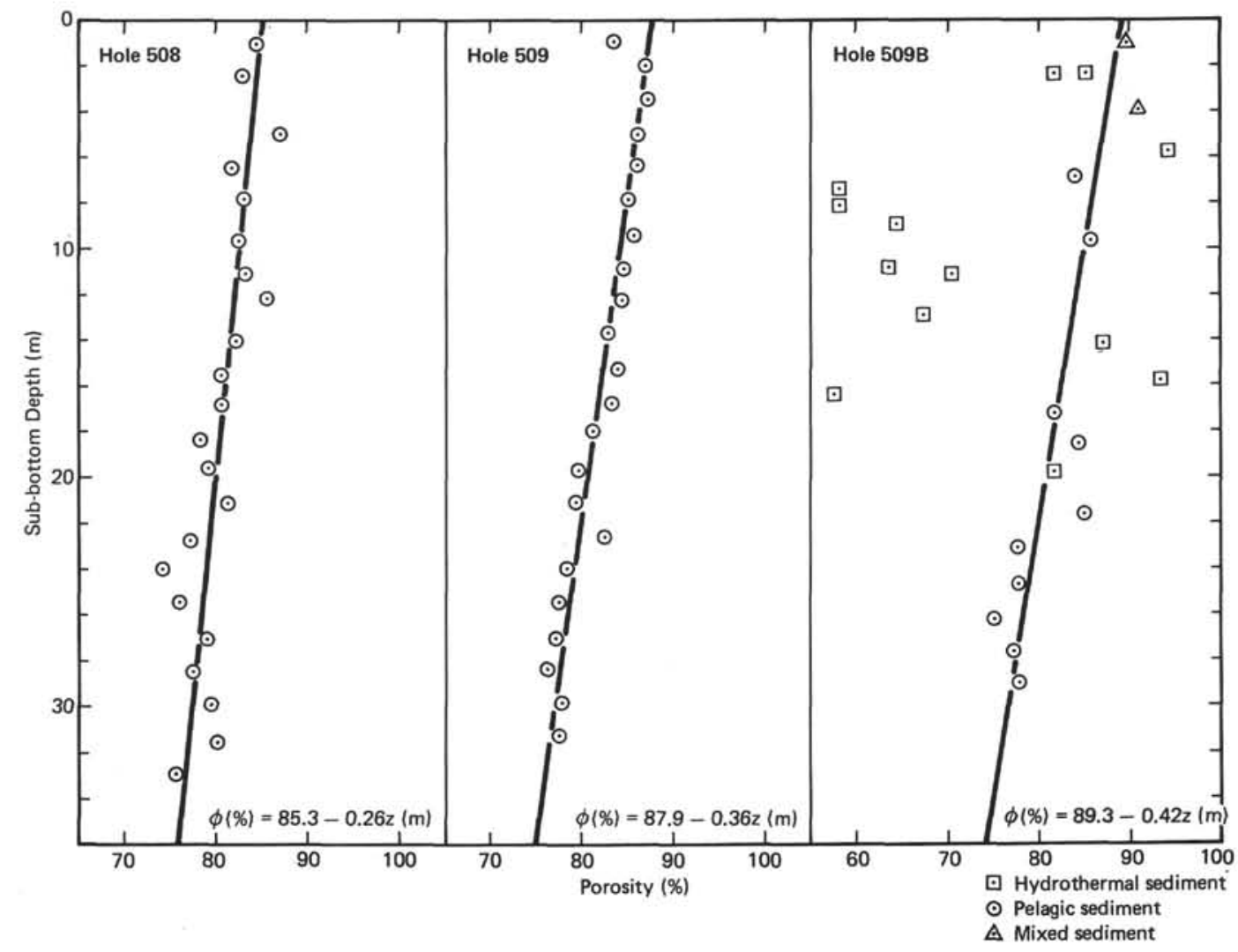

Figure 6. Porosity measurements versus depth with linear regressions (pelagic ooze samples only) for three representative holes: low heat flow, nonmound Hole 508; high heat flow, off-mound Hole 509, and mound Hole 509B. (Reprinted from Geol. Soc. Am. Bull., Pt. 1, Vol. 92.) 
signed arbitrarily to three groups: (1) Fe-rich and basemetal sulfides sometimes associated with oxides and silicates, (2) sharply fractionated oxides and silicates, and (3) widely dispersed ferromanganese oxides.

The type example of the first group could be considered as the $\mathrm{Cu}-\mathrm{Zn}-\mathrm{Fe}$-sulfide deposits within the median valley of the East Pacific Rise at $21^{\circ} \mathrm{N}$ (Francheteau et al., 1979; Hekinian et al., 1980). Helium-3 and manganese anomalies in the overlying water column attest to the discharge of rising plumes of hot vent water (Lupton et al., 1980). At the vents themselves, water is exiting from the basement at flow rates of 1 to $5 \mathrm{~m} / \mathrm{s}$ and at temperatures of up to $350^{\circ} \mathrm{C}$ (MacDonald et al., 1980). Precipitation of sulfides takes place on the seafloor, following rapid cooling of the solutions and builds tall (up to $10 \mathrm{~m}$ high) extremely irregular columns about 5 meters in diameter (Francheteau et al., 1979). Details of sulfide distribution and mineralogy are given by Hekinian et al. (1980) and by Haymon and Kastner (1981). Vents known as "white smokers," issuing from chimneys at tens of centimeters per second at temperatures of 100 to $350^{\circ} \mathrm{C}$ are also present; the fluid is clouded by white precipitates, mostly barite and silica (RISE Project Group, 1980). Localized metal sulfide deposits have also been dredged, in association with basalts, from major fracture zones in the Atlantic (Bonatti et al., 1976 a,b).

The type example of the second group of deposits could be considered the Galapagos mounds themselves. The deposits typically show a close spatial and genetic association of Mn-oxides with nontronitic iron silicates; minor amounts of $\mathrm{Fe}$ oxides such as limonite and goethite may be present near the stratigraphic tops of the deposits (Hekinian et al., 1978; Corliss et al., 1978; Williams et al., 1979). The Galapagos mounds deposits appear to be forming from hydrothermal solutions of not more than a few tens of degrees Celsius (Corliss et al., 1979; Honnorez et al., 1981; Barrett et al., this volume). Stratigraphic evidence (Hekinian et al., 1979; Honnorez, et al., 1981) indicate that as the discharging solutions react with oxygenated seawater, Fe silicates (with some admixture of $\mathrm{Fe}$ oxides) are also in some cases precipitated before the Mn oxides.

Although the group 2 deposits are best developed in the mounds field on the southern flank of the Galapagos spreading axis, mineralogically similar though much less voluminous deposits have been reported from the Gulf of Aden (Cann et al., 1977), from Transform Fault " $A$ " in the FAMOUS area of the Mid-Atlantic Ridge near $37^{\circ} \mathrm{N}$ (Lalou et al., 1977; Hoffert et al., 1978), and from the Explorer Ridge in the Northeast Pacific Ocean (Grill et al., 1981). A subclass of the group 2 deposits is the nearly pure Mn-oxide precipitates which occur as encrustations on basalts. Examples of these have been reported from near the Galapagos spreading axis (Moore and Vogt, 1976) and in the TAG area of the Mid-Atlantic Ridge (Scott et al., 1974; Rona, 1980).

The third group of deposits is best exemplified by the $\mathrm{Fe}-\mathrm{Mn}$ enriched sediments overlying basalts in the eastern Pacific, both near the spreading axis (Skornyakova,
1964; Bonatti and Joensuu, 1966; Boström, 1973; Piper, 1973), and as basal deposits recovered by the Deep Sea Drilling Project (Boström et al., 1976; Cronan, 1976; Dymond et al., 1973, 1977; and references therein). The sediments consist of varying proportions of ambient pelagic sediment (commonly carbonate-rich) and hydrothermal derived poorly crystalline $\mathrm{Fe}$ and $\mathrm{Mn}$ oxides and hydroxides. The metalliferous component was precipitated from discharging solutions at spreading axes and subsequently transported laterally and disseminated by bottom currents. A variant on this type of sediment may be the Fe-montmorillonite-rich material (more aluminous than the nontronite of the mounds area) developed in superficial sediments in the Bauer Deep, some $700 \mathrm{~km}$ east of the East Pacific Rise (Sayles and Bischoff, 1973). Opinion on the mechanism of formation of the Bauer Deep sediments is divided (Sayles and Bischoff, 1973; Heath and Dymond, 1977; McMurtry and Yeh, 1981). Similar occurrences of surficial Fe-rich montmorillonites in the Pacific have been reported by Aoki, 1974; Bischoff and Rosenbauer, 1977; and Hein et al., 1979. The consensus of opinion among the above authors is that the $\mathrm{Fe}$ component of the montmorillonite is ultimately of hydrothermal origin, though whether the hydrothermal source is local or distant is still not clear.

The Atlantis II Deep of the Red Sea contains a sequence of precipitates in the order of sulfides, then silicates, then oxides, that cover almost the whole range of groups outlined above (Bischoff, 1969). The Atlantis II Deep sequence, taken together with the data for hydrothermal deposits outlined above, allow the following inferences to be made (Edmond et al., 1979a; Cronan, 1980). Where temperatures and discharge rates are high and solutions remain reduced up to the basalt seawater interface, metal-rich sulfides will precipitate directly, as at $21^{\circ} \mathrm{N}$ on the East Pacific Rise. Where subsurface mixing occurs as a result of lower discharge rates, and therefore mixing with downward-flowing seawater takes place, subsurface sulfide precipitation occurs and low-temperature precipitates such as silicates and oxides will be deposited in the seafloor. Their location of precipitation will be determined by the Eh gradient, with the oxides depositing under most oxygenated conditions, as in the Galapagos and FAMOUS areas. Fe oxides precipitate close to the exit of the hydrothermal solutions compared to Mn oxides. If subsurface mixing of the hydrothermal end-member solution with seawater is extensive, only oxides may surface. This leads to Fe-Mn-hydroxyoxide precipitates in the case of the fast-spreading ridges (e.g., the East Pacific Rise); in the case of slow-spreading ridges (e.g., the Mid-Atlantic Ridge), where exit temperatures and discharge rates are low, only Mn oxide precipitates.

\section{BASEMENT ROCKS}

\section{Petrography}

Drilling of basalt was attempted in 13 holes representing all of the sites occupied in the Galapagos. Loose rubble and/or highly fractured rock was encountered at 
the sediment/basalt interface at all sites. The difficulty in drilling into such material resulted in low total penetration and recovery (approximately 15\%).

Young crust at Sites 506, 507, and 508 yielded nearly identical samples of fine- to medium-grained, aphyric to sparsely plagioclase phyric basalt. Textures range from glassy to ophitic/intergranular. Plagioclase is the dominant phenocryst phase $(<5 \%)$ with very subordinate clinopyroxene ( $<3 \%$ ?). Microlites and small crystals of plagioclase and clinopyroxene compose the interstitial matrix and form quenched textures. Titanomagnetite, which makes up $8 \%$ to $13 \%$ of the nonglassy samples, is the dominant opaque phase and appears to be partly replaced by titanomagnetite. Primary spherules of sulfide minerals, never exceeding $1 \%$, accompany the titanomagnetite.

At Site 510, fine- to medium-grained, moderately ( $2 \%$ to $10 \%)$ plagioclase-rich, sparsely $(1 \%$ to $2 \%)$ olivine phyric basalt was recovered. Titanomagnetite is less abundant at Site 510 than at Sites 506 to 508, ranging from $3 \%$ to $8 \%$ of the rock.

Comparisons of the phenocryst assemblages, $\mathrm{Fe}-\mathrm{Ti}$ oxides, and chemical analyses show that the young basalts recovered near the spreading center on Leg 70 are derived from ferrobasaltic magmas, whereas intermediate-aged basalts are typical oceanic tholeiites. Ferrobasalts and fractionating plagioclase and clinopyroxene have been postulated as erupting from rather shallow magma reservoirs below the Galapagos Spreading Center (Schilling et al., 1976; Clague and Bunch, 1976).

The ${ }^{87} \mathrm{Sr} / 86 \mathrm{Sr}$ ratio of four mounds area basalts from subbasement depths of $<15$ meters displays a small range of 0.70256 to 0.70278 with an average of 0.70268 , indistinguishable from the average value of 0.70265 for fresh midocean ridge basalts (Barrett, this volume). Oxygen isotope ratios of four bulk-rock Galapagos area basalts have a mean $\delta^{18} \mathrm{O}$ value of $5.8 \pm 0.1 \%$, also characteristic of fresh midocean ridge basalts.

\footnotetext{
Alteration

Most of the basalt samples from Site 506 appear to be fresh, but a few samples are slightly altered, as indicated by the presence of smectite in vesicles and interstitial voids. A thin $(<4 \mathrm{~mm})$ rim occurs in a few samples.

At Site 507, the basalt texture clearly influences the alteration. The subophitic basalts seem to be fresh, whereas the hyalopilitic basalts are altered and show dark alteration rims (average thickness, $8 \mathrm{~mm}$; maximum thickness, $15 \mathrm{~mm}$ ) subparallel to exposed surfaces and fissures. These alteration rims correspond to vesicles and miarolitic voids infilled by alteration minerals. These are, in order from the exposed surface to the centers of the samples: (1) iron oxyhydroxides, (2) green smectite (in the rims of vesicle infillings), and (3) iron oxyhydroxides (in their centers); (4) green smectite. All of the voids in the centers of the samples are empty.

At Site 508, all of the samples exhibit altered rims, sometimes up to $50 \mathrm{~mm}$ thick. Alteration mineral zonation was observed as follows from the exterior to the center of the samples (1) iron oxyhydroxides + green smectite + brown smectite(?); (2) green smectite; (3)
}

brown smectite. Empty voids are always found in the centers of the fresher appearing samples. A drusy mineral, possibly zeolitic, has been observed in some vesicles.

At Site 510, the thickness of the alteration rims ranges from 5 to $40 \mathrm{~mm}$, averaging roughly $15 \mathrm{~mm}$. Alteration also appears to be controlled by fissures, cracks, and exposed surfaces. In the alteration rims, the pore spaces are often filled by the following secondary mineral sequence, starting from the exposed surface to the core of the sample: (1) bright green smectite, (2) brownish green smectite, and (3) very pale brown smectite. Secondary mineral sequences are sometimes more complex. For instance, the following paragenetic succession from the rock interior through an alteration rim was observed adjacent to a smectite veinlet: (1) $\mathrm{Fe}(\mathrm{OH})_{\mathrm{n}}$ (not always present), (2) orange-brown smectites with $\mathrm{Fe}(\mathrm{OH})_{\mathrm{n}}$, (3) mixed orange-brown and green smectites (and possible calcite), (4) green smectite (and possible zeolite), (5) very light brown smectite. A secondary mineral paragenetic succession in another veinlet, from pyrite along the walls through various smectites to $\mathrm{Fe}$-oxyhydroxides in the center, indicates that the conditions changed from anoxic to oxic or suboxic.

Figure 7 illustrates the variation in the secondary mineral paragenetic sequence with age observed in alteration rims of Galapagos basalts. This figure shows that the mean widths of the alteration rims increase with age from Site 506 to 508 , that is, between 0.54 and $0.85 \mathrm{~m}$.y. Alteration minerals can be readily explained by the interaction between basalt and seawater at low temperature, although some higher temperature hydrothermal alteration may also be invoked.

\section{Physical Properties}

Because of the low recovery of basalts, physical property measurements were carried out on only a limited number of samples. The shipboard and shore laboratory results are given by Karato (this volume). On the average, basalts from the Galapagos and nearby Costa Rica Ridge have high grain densities and low porosities and, as a result, high wet-bulk densities, compared with DSDP samples from other areas.

The permeability of unfractured basalts is, on average, $1.3 \times 10^{-16} \mathrm{~cm}^{2}$, which is much smaller than the average permeability of the basement $\left(10^{-10}\right.$ to $10^{-11}$ $\mathrm{cm}^{2}$ ). This suggests that the bulk of hydrothermal flow occurs through fissures, cracks, and/or faults.

The anomalously high depth gradients in physical properties are the result of a process at the basement/sediment interface which is probably produced by hydrothermal flow. This is supported by the good correlation found between gradients in physical properties with depth and heat flow. Further, the change from anomalous to normal depth gradients occurs at 30 to 50 meters sediment thickness. This suggests that the sealing off of direct discharge of hydrothermal flow through the sediment layer occurs at this sediment thickness. This assumption yields a reasonable estimate of the average permeability through the basement layer as $(2 \sim 5)$ $\times 10^{-10} \mathrm{~cm}^{2}(20 \sim 50$ mdarcy $)$. 

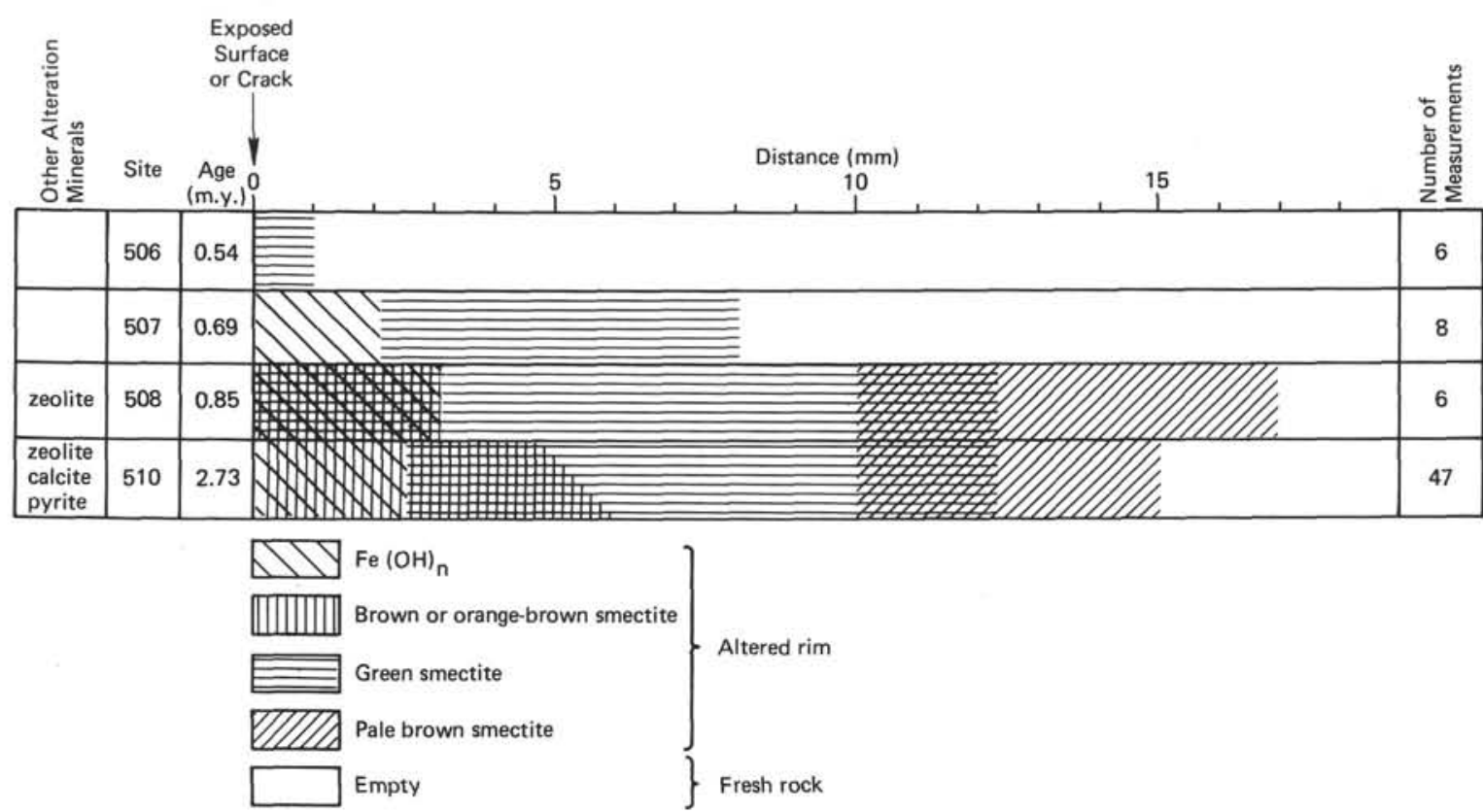

Figure 7. Variation of the average thickness and nature of the infillings in the altered rim of basalts with age. (Reprinted from: Geol. Soc. Am. Bull., Pt. 1, Vol. 92.)

In addition, a good correlation between present-day heat flow and the gradients of physical properties with depth is consistent with the idea that the hydrothermal circulation is moving along with the plate. It is not fixed with respect to a reference point such as the ridge crest (see Karato and Becker, this volume).

\section{Paleomagnetism}

Table 8 summarizes the results of paleomagnetic measurements of basement basalt samples carried out on board D/V Glomar Challenger. The NRM intensity of the natural remanent magnetization, $\bar{J}_{\mathrm{NRM}}$, is of key importance in modeling the thickness of the layer responsible for the marine magnetic anomalies. There is no significant difference between $\bar{J}_{\mathrm{NRM}}$ at the youngest Site 506 and at those of intermediate age, Sites 507 and 508. $\bar{J}_{\mathrm{NRM}}$ is approximately equal to $20 \times 10^{-3} \mathrm{G}$ for Sites 506, 507, and 508. This value is extremely high relative to other oceanic basalts, especially considering the equatorial location of the sites, and, indeed, it is comparable to values of new crust in the FAMOUS area of the Mid-Atlantic Ridge (Johnson and Atwater, 1977) Furthermore, $\bar{J}_{\text {NRM }}$ value for these sites is very similar to the value of $25 \times 10^{-3} \mathrm{G}$ used by Sclater and Klitgord (1973) to model the central anomaly. Thus, it appears that the assumption of a 500-meter-thick magnetized layer to explain the observed anomalies is a rather good approximation in this area.

Despite its relatively high value, $\bar{J}_{\mathrm{NRM}}$ of Sites 506 , 507 , and 508 is only about one-third that of zero-age samples from the Galapagos Spreading Center, just 19 to $26 \mathrm{~km}$ north of these sites (Anderson et al., 1975; Levi, 1980). The precise cause of the decrease of $\bar{J}_{\text {NRM }}$ relative to that at the spreading center must await further study. However, previous work in the Atlantic Ocean (Irving et al., 1970) has shown that low-temperature oxidation of the primary titanomagnetite is an important mechanism for the decrease of $\bar{J}_{\mathrm{NRM}}$ with distance (age) from the spreading axis. $\bar{J}_{\mathrm{NRM}}$ at Site 510 is less than one-third that at the younger sites; this is thought to be too much of a decrease to be accounted for entirely by progressive low-temperature oxidation (since the initial decrease of $\bar{J}_{\text {NRM }}$ had already occurred between the ridge crest values and the younger sites). Preliminary petrographic observations indicate that the Site 510 basement rocks are not ferrobasalts. Hence,

Table 8. Average magnetic properties of Leg 70 sites at GSC near $86^{\circ} \mathrm{W}$ (from Levi, this volume).

\begin{tabular}{|c|c|c|c|c|c|c|}
\hline Site & $\begin{array}{l}\text { Basement } \\
\text { Age (m.y.) }\end{array}$ & $J_{\mathrm{NRM}^{\mathrm{a}}}{ }^{\mathrm{a}}$ & $x^{a}$ & $Q^{\mathrm{a}}$ & $\mathrm{MDF}^{\mathrm{a}}$ & $T_{\mathrm{c}}^{\mathrm{a}}$ \\
\hline 506 & 0.54 & & & & & \\
\hline 507 & 0.69 & $19.6 \pm 9.0^{\mathrm{b}}(20)^{\mathrm{c}}$ & $1.58 \pm 0.73(21)$ & $45 \pm 28(20)$ & $157 \pm 57(17)$ & $197 \pm 31(6)$ \\
\hline 508 & 0.85 & & & & & \\
\hline 510 & 2.73 & $5.6 \pm 4.2 \quad(29)$ & $0.88 \pm 0.34$ (29) & $21 \pm 14(29)$ & $173 \pm 73(18)$ & $271 \pm 15(5)$ \\
\hline
\end{tabular}


Site 510 is just outside the zone of the high-amplitude magnetic anomalies.

$Q$, the ratio of remanent to induced magnetization, is high at all sites, indicating the dominance of the remanent with respect to the induced magnetization, a finding consistent with the existence of distinct magnetic anomaly profiles. $Q$ progressively decreases with age.

However, this trend is not repeated by the MDF (median demagnetizing field) values. The relatively high MDF values suggest that the remanence at all four Galapagos sites resides in fine particles of titanomagnetite. The stability of the remanence is further demonstrated by the small change in remanence direction upon AF (alternating field) demagnetization. The shallow inclinations measured on samples from all four sites are consistent with the equatorial locations of the sites. The present inclination at the sampling sites is about $+21^{\circ}$, and that expected from a geocentric axial dipole is very near zero.

Thermomagnetic analysis of the basalts shows an increase in Curie points $\left(T_{c}\right)$ with age, probably the result of titanomagnetite oxidizing to titanomaghemite. The mean $T_{c}$ determined for Sites $506-508\left(197^{\circ} \mathrm{C}\right)$ is significantly higher than that determined for Site $424\left(\bar{T}_{c}\right)=$ $143^{\circ} \mathrm{C}$, Petersen and Roggenthen, 1980). This is probably a result of the fact that basalts at Site 424 consist of coarser titanomagnetite grains, which are magnetically less stable and more resistant to oxidation.

\section{HEAT FLOW}

Downhole sediment temperatures were successfully measured by a probe which penetrated undisturbed sediments below the drill bit immediately adjacent to several HPC holes at Sites 506 to 509; measurements were also made during the process of drilling the single hole at Site 510. The results are summarized in Table 9 (Becker et al., this volume). This table is similar to that given in Honnorez et al. (1981), except that the heat flow and thermal regime values are changed as a result of more careful analysis of the data. Temperatures were determined by monitoring the resistance of a single thermistor, intruding about 1 meter into the sediment, to a precision of $10 \mathrm{ohms}$ - providing a nominal temperature resolution of about $0.1^{\circ} \mathrm{C}$. At Sites 506 through 509, two or three stops were characteristically made at 8- to

Table 9. Galapagos Spreading Center heat-flow results (Becker et al., this volume).

\begin{tabular}{|c|c|c|c|c|}
\hline $\begin{array}{l}\text { Measurement } \\
\text { Hole }\end{array}$ & $\begin{array}{c}\text { Nearest } \\
\text { Corresponding } \\
\text { Drill Hole }(\mathrm{s})\end{array}$ & $\begin{array}{l}\text { Thermal Cond. } \\
(\mathrm{Z}=\text { meters of sed.) } \\
\left(\mathrm{Wm}^{-1} \mathrm{~K}^{-1}\right)\end{array}$ & $\begin{array}{l}\text { Surface } \\
\text { Heat Flow } \\
\left(\mathrm{mWm}^{-2}\right)\end{array}$ & $\begin{array}{l}\text { Thermal } \\
\text { Regime }\end{array}$ \\
\hline $506 \mathrm{E}$ & 506 (mound) & $0.79 \pm 0.005 \mathrm{Z}$ & 570 & $\mathrm{C}$ ? \\
\hline $506 \mathrm{~F}$ & $506 \mathrm{~B}$ (off-mound) & $0.72 \pm 0.015 Z$ & 620 & $\mathrm{c}$ \\
\hline $507 \mathrm{~A}$ & $\begin{array}{l}507,507 \mathrm{~B} \\
\text { (off-mound?) }\end{array}$ & $0.76 \pm 0.009 \mathrm{Z}$ & 436 & $\mathrm{C}$ \\
\hline 507E & 507D (mound) & $0.66 \pm 0.009 \mathrm{Z}$ & 327 & Cord? \\
\hline $507 \mathrm{G}$ & 507F (mound?) & $0.76 \pm 0.009 \mathrm{Z}$ & 530 & $\mathrm{D}\left(6 \times 10^{-7}\right)$ \\
\hline 5071 & $507 \mathrm{H}$ (off-mound) & $0.79 \pm 0.007 \mathrm{Z}$ & 234 & $R\left(7 \times 10^{-7}\right)$ \\
\hline $508 \mathrm{~A}$ & & & 90 & $\mathrm{R}\left(1.0 \times 10^{-6}\right)$ \\
\hline $508 \mathrm{D}$ & 508 (pelagic) & $0.78 \pm 0.007 \mathrm{Z}$ & 228 & $\mathrm{C}$ \\
\hline $508 \mathrm{E}$ & & & 76 & $\mathrm{R}\left(1.7 \times 10^{-6}\right)$ \\
\hline $509 \mathrm{C}$ & 509B (mound) & $0.72 \pm 0.011 \mathrm{Z}$ & -700 & $\mathrm{D}$ ? \\
\hline $509 \mathrm{D}$ & 509 (off-mound) & $0.74 \pm 0.010 Z$ & 509 & C \\
\hline 510 & 510 (pelagic) & $0.89 \pm 0.06$ & 193 & C \\
\hline
\end{tabular}

Note: $\mathrm{C}=$ conductive; $\mathrm{D}=$ discharge; $\mathrm{R}=$ recharge (flow rates in $\mathrm{cm} / \mathrm{s}$ ); ? = not well determined. 10-meter intervals for temperature determinations in the 30-meter-thick sediment columns. In most cases, the estimated precision of the measured thermal gradients is 0.05 to $0.1^{\circ} \mathrm{C} / \mathrm{m}$ as a result of several sources of experimental error. Among these are inaccuracies in determining and maintaining the probe position to better than \pm 1 meter relative to the sediment/water interface and errors in the temperature observations resulting from some combination of instrument drift, possible water circulation about the probe, and probe motion resulting from the low shear strength of the sediments. Normally, such imprecision in gradients would produce large uncertainties in heat-flow values, but in this area of high heat flow, it results in errors of only $5 \%$ to $10 \%$.

Sediment thermal conductivities were measured on board the D/V Glomar Challenger at close intervals (1 to $2 \mathrm{~m}$ ) in all cores by the needle-probe method (Von Herzen and Maxwell, 1959) and were corrected to in si$t u$ conditions using the relation of Ratcliffe (1960), as modified by Hyndman and others (1974). Equipment uncertainties limited the accuracy of shipboard conductivity measurements to $\pm 10 \%$; previously reported values average about $5 \%$ lower than ours, which may therefore be as much as $5 \%$ too high. Nevertheless, the relative variation of conductivity, both among sites and downhole, was well determined. At each site, conductivities were found to increase rapidly with depth within 30 to 50 meters of basement, with a gradient of about 0.20 $\mathrm{mcal} / \mathrm{cm} \mathrm{s}{ }^{\circ} \mathrm{C} / \mathrm{m}(0.01 \mathrm{~W} / \mathrm{mK} / \mathrm{m})$. Except at Site 510 , linear increases of thermal conductivity with depth fit the data significantly better than do mean values and hence were used in calculating heat flows. For a constant conductive heat flow, this linear increase of conductivity with depth should be coupled with a corresponding decrease in the temperature gradient with depth. Indeed, most temperature profiles were found to be nonlinear with depth, but not always in the sense required for purely conductive heat flow. These nonconductive, nonlinear profiles were fit to a steady state, one-dimensional fluid flow equation (Bredehoeft and Papadopulos, 1965), modified for the depth variation of conductivity, to yield the apparent pore-water flow rates given in Table 9. These values are probably no better than order-of-magnitude estimates; nevertheless, we believe that they reflect real differences in the thermal processes occurring at the various mounds and pelagic core sites.

Despite the relatively large measurement uncertainties, our heat-flow values agree well with detailed surface heat-flow contours based on several hundred short probe measurements in the immediate area (Sclater and Klitgord, 1973; Williams et al., 1974; Green et al., 1980). The deeper penetration of our measurements gives better resolution of fluid flow processes in sediments. These processes may be coupled to those in the more permeable basement rocks inferred to be responsible for the regular variation of heat flow at the Galapagos Spreading Center.

The heat-flow values in the vicinity of mounds are very high. Temperature profiles at three of the four mounds measurement holes are nonlinear in a sense consistent with convective hydrothermal discharge at 
rates of the order of $0.5 \times 10^{-6} \mathrm{~cm} / \mathrm{s}(15 \mathrm{~cm} / \mathrm{y}$.). None of our other measurements displayed this type of nonlinearity. At all three mound sites (506, 507, and 509), holes drilled in pelagic sediments nearby $(0.1$ to $0.5 \mathrm{~km})$, but off the mounds, had conductive or apparent recharge (507I) temperature profiles, indicating that the apparent hydrothermal discharge at the mounds is quite localized, as has been proposed in models of this process (Spooner and Fyfe, 1973; Lonsdale, 1977) and observed in hydrothermal fields such as the Reykjanes Peninsula in Iceland (Palmason, 1967).

At the low heat-flow site (508), where only pelagic sediments were cored, three heat-flow measurements made quite close together gave somewhat conflicting results. Surface heat flows were relatively low, but ranged from 1.8 to $5.4 \mathrm{HFU}\left(75-230 \mathrm{~mW} / \mathrm{m}^{2}\right)$. Two of the three temperature profiles (Holes 508 and 508E) were strongly nonlinear and displayed curvature consistent with recharge (downward flow of bottom water through the sediments) at rates of the order of $10^{-6} \mathrm{~cm} / \mathrm{s}(30$ $\mathrm{cm} / \mathrm{y}$.). The association of downward water flow with relatively low heat flow supports the inference of convective recharge at heat-flow minima in a cellular pattern (Williams et al., 1974; Green et al., 1981).

\section{DISCUSSION}

The models of mounds formation that have been developed must be constrained by all existing data. In the following paragraphs, we summarize the relevant observations made over the past decade on these mounds.

1) The mounds are located 20 to $30 \mathrm{~km}$ south of the Galapagos Spreading Center over crust 0.5 to 0.9 m.y. in age, where the sediment is 25 to 50 meters thick. Mounds are not found over younger crust to the north, although some mounds may be buried by thicker sediments on older crust to the south. The mounds are found only on the south flank of the Galapagos Spreading Center, although appropriate near-bottom survey data are hardly adequate on the north flank.

2) The mounds are frequently located over small (less than a few meters), vertical displacements of the upper basement rock surface (Lonsdale, 1977).

3) The mounds are located in a region of high heat flow ( 8 to $10 \mathrm{HFU}$ ), with extremely high and localized heat flow $\left(10^{2}-10^{3}\right.$ HFU) associated with some mound peaks (Williams et al., 1979). Our data show that nonlinear temperature and chemical gradients are generally of a distinctive character between on and off mounds sites, usually concave downward in the former and concave upward in the latter. We interpret these profiles to indicate vertical advection of hydrothermal solutions through the entire mounds region. These solutions may be rising one or two orders of magnitude more rapidly in the mounds proper than in the seafloor surrounding the mounds.

4) Although temperatures up to $15^{\circ} \mathrm{C}$ were measured within the mounds, extensive surveys show no measurable active hydrothermal venting over mounds, unlike the spreading center to the north (Corliss and others, 1979a).

5) As observed from bottom photographs and submersibles, mound surfaces are composed of acoustically reflective Mn-oxide crusts, with associated iron oxides and smectites of yellow or orange color (Corliss et al., 1978; Williams et al., 1979).

6) The sedimentary stratigraphy of mounds determined from cores recovered during DSDP Leg 70 drilling consistently shows three units (Fig. 8), from uppermost to lowermost: (I) a siliceous foraminifer-nannofossil ooze, usually capped with a surface layer of "oxidized" pelagic mud, and generally overlying, with a sharp contact (II) interbedded pelagic and hydrothermal sediments, which always progressively grade downwards into (III) a foraminifer-nannofossil ooze, underlain by basement.

7) The biogenic siliceous component of pelagic sediments decreases more rapidly with depth at mounds sites than at off-mounds sites.

8) The hydrothermal layers of Unit II lack carbonate and siliceous organisms, and their composition is similar to those of equivalent nontronitic clays and Mn oxides which have been ascribed to hydrothermal activity near the Galapagos Spreading Center and at other locations of the world rift system (Bischoff, 1972; Corliss et al., 1978; Scott et al., 1974; Moore and Vogt, 1976; Hoffert et al., 1978; Hoffert et al., 1980).

9) The bulk of the hydrothermal material is confined both vertically and horizontally within the vicinity of the mounds.

10) Although recovery was poor, the uppermost few meters of basement rock, drilled both on and off mounds, show little evidence of high temperature hydrothermal alteration.

Most of these observations lead us to support previously suggested models of mounds formation as a result of precipitation of materials from hydrothermal solutions (Klitgord and Mudie, 1974; Lonsdale, 1977; Corliss et al., 1978; Williams et al., 1979). However, the success of our mounds drilling allows us to narrow the range of specific models.

If we accept the observation made with the submersible Alvin by Williams et al. (1979) that the tops of the Galapagos mounds are active and covered by $\mathrm{MnO}_{2}$ crusts, then we can assume that Hole 509B was drilled close to the top of an active mound, because heat-flow measurements show this hole to be a discharge site (Becker et al., this volume) and the topmost cores contain a substantial thickness of Mn-oxide crust fragments. The other mounds holes, on the other hand, were drilled in the flanks of active mounds away from their $\mathrm{MnO}_{2}$-bearing top, or in inactive mounds. Other holes from which were recovered substantial thicknesses of nontronite, but only very minor amounts of the oxide crust, were probably located on the flanks of mounds, where hydrothermal solutions were slowly flowing. We infer that because no surficial precipitates are presently forming on these flanks, pelagic sediment is able to accumulate to thicknesses of up to a few meters.

Williams et al. (1979) recovered Mn-rich birnessite and lesser todorokite, amorphous Fe oxides, and semilithified nontronite from blocky surfaces and knobs at the tops of mounds. Leg 70 did not intersect this mineral association at the mounds sites. However, given the pelagic sediment overlying the hydrothermal layers, it is 


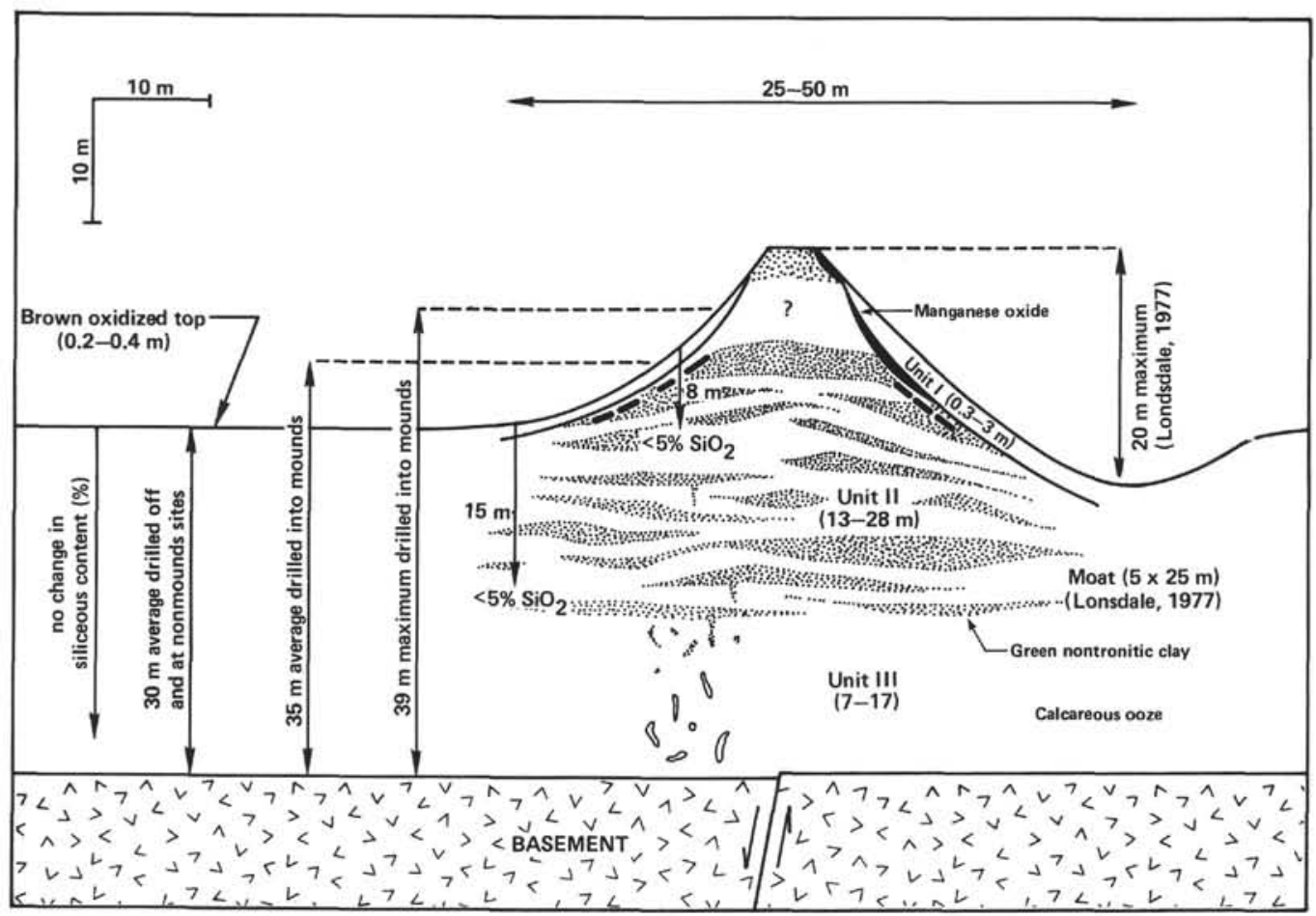

Figure 8. Idealized diagram of the internal structure and dimensions of a mound. (Adapted from: Geol. Soc. Am. Bull., Pt. 1, Vol. 92.)

quite possible that we may not have drilled on the axis of an active mound, but rather on a mounds flank or on a mound which had not been actively depositing metalliferous sediment for some time. Use of submersibles should provide direct observation of the exact location of Leg 70 bore holes with respect to mound geometry. However, hydrothermal activity is nevertheless taking place, as indicated by the heat-flow measurements and by pore-water analyses.

Although no obvious hydrothermal venting takes place over the mounds, in contrast to the spreading center to the north (Corliss et al., 1979), temperatures of up to $15-20^{\circ}$ are inferred from heat-flow data for the basalt/sediment contact under the mounds (Becker et al., this volume), and temperatures of up to $11.5^{\circ} \mathrm{C}$ have been measured in situ at a depth of 9 meters within the mounds (Williams et al., 1979). Pore waters at mounds sites are enriched in $\mathrm{Ca}$ relative to both seawater and to the low heat-flow site (508). This reflects upward flow through the sediments of seawater which has gained $\mathrm{Ca}$ and lost $\mathrm{Mg}$ probably as a result of earlier reaction with the basaltic basement (Bender, this volume). The $\mathrm{Si}$ and $\mathrm{NH}_{3}$ concentrations of mounds pore waters increase upcore as a result of the addition of dissolving biogenic debris to ascending hydrothermal solutions (Bender, this volume). Such dissolution is also reflected in the observation that the biogenic siliceous component of pelagic sediments decreases more rapidly with depth at mounds sites than at off-mounds sites (Moorby et al., this volume). Given these observations, and the fact that Leg 70 drilling demonstrated the confinement of hydrothermal material to the immediate vicinity of the mounds, the following general model for mounds development can be inferred.

Mounds form above localized, probably more permeable regions of crust which have been disrupted by faulting. Hydrothermal solutions percolate slowly upward through the sediments, interacting with both sediments and seawater to form mounds by precipitation of hydrothermal sediments. Within the mounds, the interfingering of hydrothermal products and normal pelagic sediments, and the gradational contacts between these lithologies, suggest that transformation from one lithology to the other has taken place and that this is a subsurface reaction. Although some surface precipitates of the type observed by Williams et al. (1979) at mound pinnacles could take place through direct precipitation on the seafloor, we believe that most of the hydrothermal material, in particular the nontronite, is of subsurface origin.

The stratigraphic occurrence of nontronite beneath Mn-oxide crusts suggests that the oxidation profile in the mounds leads to the sequential upward precipitation of Fe and Mn (cf. Cann et al., 1977; Corliss et al., 1978). $\mathrm{The} \mathrm{Fe}$, and perhaps part of the $\mathrm{Si}$, are probably derived from reduced solutions advecting upward from the basaltic basement. Bender (this volume) found that pore waters in mounds and off-mounds holes are enriched in $\mathrm{Fe}$ relative to seawater.

The near uniform composition of nontronites recovered by Leg 70 (Fe-rich, low $\mathrm{Mg}$ and $\mathrm{Al}$ contents) is consistent with relatively constant solution composition during nontronite formation. For instance, the $\mathrm{Mg}$ and $\mathrm{Al}$ contents of the solutions must have been uniformly 
low, otherwise compositionally different smectite minerals would have formed. Mn-oxide crusts probably form only very near or at the surface of the mounds because of the need for oxidizing conditions (as provided by bottom seawater) to precipitate Mn.

The oxidant required for the precipitation of nontronite is more problematic. If ascending solutions bearing $\mathrm{Fe}^{2+}$ encounter Mn-oxide crusts near the mounds surface, the $\mathrm{Fe}^{2+}$ may reduce the $\mathrm{Mn}^{4+}$, dissolve the crust, and be oxidized to $\mathrm{Fe}^{3+}$, which is required for nontronite formation. Reduction of $\mathrm{NO}_{3}$ can also provide the $\mathrm{O}_{2}$ needed to oxidize ferrous iron. However, downward diffusion of these oxidants is probably limited to the top 10-20 cm of sediment (Bender, this volume). If substantial near-surface Mn-oxide crust material is absent, or, as suggested by the presence of transitional nontronite layers, if nontronite forms primarily at depth, then another oxidant is required.

Charge-balance considerations put useful constraints on how the iron in the hydrothermal solutions is converted into $\mathrm{Fe}$-oxyhydroxides or nontronite in the mounds. On the one hand, the iron in the ascending solutions is most probably reduced, $\mathrm{Fe}^{3+}$ being insoluble except in very acidic solutions. On the other hand, the iron in Fe-oxyhydroxides or nontronite is completely or mainly trivalent, and $\mathrm{Fe}_{4} \mathrm{Si}_{8} \mathrm{O}_{20}(\mathrm{OH})_{4}$ can be taken as a simple formula of this clay mineral. Therefore, an essential component of nontronite formation is the oxidation of $\mathrm{Fe}^{2+}$. Three oxidants are capable of energetically oxidizing ferrous iron: $\mathrm{O}_{2}, \mathrm{NO}_{3}{ }^{-}$, and $\mathrm{MnO}_{2}$. The overall reaction involving $\mathrm{O}_{2}$ is:

$$
4 \mathrm{Fe}^{2+}+8 \mathrm{SiO}_{2}+\mathrm{O}_{2}+6 \mathrm{H}_{2} \mathrm{O} \rightarrow \mathrm{Fe}_{4} \mathrm{Si}_{8} \mathrm{O}_{20}(\mathrm{OH})_{4}+8 \mathrm{H}^{+}
$$

One mechanism for oxidation is the downward diffusion of $\mathrm{O}_{2}$ and/or $\mathrm{NO}_{3}{ }^{-}$from the sediment/water interface. For normal diffusion rates, calculations show that nontronite would have to be forming within a few centimeters of the interface to match the sedimentation rate in this region $\left(\sim 5 \mathrm{~cm} / 10^{3} \mathrm{y}\right.$.). The calculations for reasonable concentrations of oxidants in the bottom waters $\left(\mathrm{O}_{2}=10^{-4} \mathrm{M} ; \mathrm{NO}_{3}{ }^{-}=0.4 \times 10^{-4} \mathrm{M}\right)$ give required water fluxes of a few tens of centimeters per year, rates which are quite consistent with measured temperature and chemical gradients.

An important feature of reaction (1) is that protons $\left(\mathrm{H}^{+}\right)$are produced which can drive calcite dissolution according to the following equation:

$$
\begin{gathered}
4 \mathrm{Fe}^{2+}+8 \mathrm{SiO}_{2}+\mathrm{O}_{2}+6 \mathrm{H}_{2} \mathrm{O}+8 \mathrm{CaCO}_{3}- \\
\mathrm{Fe}_{4} \mathrm{Si}_{8} \mathrm{O}_{20}(\mathrm{OH})_{4}+8 \mathrm{Ca}^{2+}+8 \mathrm{HCO}_{3}^{-}
\end{gathered}
$$

Similar reactions can be formulated for $\mathrm{NO}_{3}{ }^{-}$and $\mathrm{MnO}_{2}$ reduction. The generation of acid during nontronite formation presumably drives the dissolution of $\mathrm{CaCO}_{3}$ and helps account for the purity of the nontronite in the sediments. If nontronite is formed by oxygen reduction, for example, 8 moles of $\mathrm{CaCO}_{3}$ (with a volume of $1,500 \mathrm{~cm}^{3}$ ) are dissolved per mole of nontronite produced (with a volume of $900 \mathrm{~cm}^{3}$ ), resulting in a $40 \%$ volume reduction of the sediment column. This might explain the presence of the moats around the mounds. One can show that if the $\mathrm{Fe}^{3+} / \mathrm{Fe}^{2+}$ ratio in the precipitated nontronite is less than 3 , the absence of $\mathrm{CaCO}_{3}$ in the nontronite layer must be ascribed to another mechanism, such as the winnowing of biogenic debris after it falls on the hard Mn-oxide crust of the mounds.

The lack of biogenic $\mathrm{SiO}_{2}$ in mounds sediments may also be a result of dissolution by ascending solutions. Calculations show that pore waters ascending at rates of a few tens of $\mathrm{cm} / \mathrm{y}$. can dissolve all of the silica at the present rate of accumulation if they acquire silica in solution at a concentration of a few hundred $\mu \mathrm{Ml}^{-1}$. It is fairly clear that the siliceous and/or carbonate microfossils are being replaced by nontronite and/or are dissolved by hydrothermal solutions (Borella et al., this volume).

The evidence uniquely provided from drilling, that $\mathrm{MnO}_{2}$ generally overlies nontronite, suggests a mechanism for nontronite formation by the replacement of $\mathrm{MnO}_{2}$ accompanied by $\mathrm{CaCO}_{2}$ dissolution according to the following equation:

$$
\begin{gathered}
4 \mathrm{Fe}^{2+}+8 \mathrm{SiO}_{2}+2 \mathrm{MnO}_{2}+4 \mathrm{H}_{2} \mathrm{O}+4 \mathrm{CaCO}_{3} \rightarrow \\
\mathrm{Fe}_{4} \mathrm{Si}_{8} \mathrm{O}_{20}(\mathrm{OH})_{4}+2 \mathrm{Mn}^{2+}+4 \mathrm{Ca}^{2+}+4 \mathrm{HCO}_{3}^{-}
\end{gathered}
$$

A similar equation can be developed for the reduction of $\mathrm{NO}_{3}{ }^{-}$. This could be accomplished by either continuous or sudden (batch) replacement of $\mathrm{MnO}_{2}$ by nontronite. The continuous upward growth of nontronite at the expense of $\mathrm{MnO}_{2}$ would account for the scarcity of $\mathrm{MnO}_{2}$ crusts at depth in the mounds sediments. The interlayering of pure nontronite and pelagic sediments may be better explained by batch replacement of the pelagic sediment by nontronite.

On the basis of the 10 meters or so of basal carbonate ooze at mounds sites, it can be inferred, given the regional sedimentation rate of $50 \mathrm{~m} / \mathrm{m} . \mathrm{y}$., that hydrothermal sediment began to form at about 200,000 years after formation of the underlying basement. In fact it probably began far more recently, because the region from the spreading axis to about $15 \mathrm{~km}$ from the spreading axis (representing about 400,000 years of spreading) is characterized by relatively low heat flow, thin sediments, and a lack of mounds. This would also imply that some pelagic sediment in the mounds has been replaced by nontronite; otherwise, all other factors being equal, the lower unit of unmineralized pelagic sediment should have a thickness of about 20 meters-significantly greater than that observed. It is possible, in fact, that within the last few 10,000 years, large-scale replacement of earlier pelagic sediment by nontronite has occurred (Williams et al., 1979).

Very high gradients in the physical properties of sediments occur within 30 to 50 meters of the basalt basement at Sites 506-510. It is interesting that this is also the sediment thickness where the mounds are presently found, and this similarity may not be coincidental. The large physical properties gradients may be interpreted as resulting from rapid dewatering or from another process which reduces the porosity of the earliest sediments deposited on young ocean crust. Since proximity to 
basement seems to be the controlling factor, it seems logical to associate this effect with hydrothermal circulation. A sediment depth of 30 to 50 meters may be the critical thickness at which hydrothermal solutions can effectively interact with the sediments in the Galapagos area (Williams et al., 1979). For younger crust with thinner sediments, the hydrothermal fluids may exchange with seawater primarily through permeable rock outcrops, bypassing the less permeable sediments. On older crust, the exchange of hydrothermal waters with seawater may be effectively suppressed by the thicker sediments. In any case, although the exact cause of the physical properties gradients has not been determined, the association of mounds formation with sediment depths comparable to those in which large physical properties gradients occur suggests a common origin for both.

The change from anomalous to normal depth gradients in physical properties at sediment thicknesses of 30 to 50 meters above basement suggests that discharge or recharge of hydrothermal solutions through sediments may be inhibited for greater thicknesses, at least for the Galapagos region. Karato and Becker (this volume) use this observation to deduce the average permeability of the basement rock layer to be about $10^{-10}$ to $10^{-9} \mathrm{~cm}^{2}$ (10 to 100 mdarcy), comparable to that deduced by Williams et al. (1979) by a similar method and by Anderson et al. (1977) using an independent method. This permeability is much greater than that measured on the unfractured basalt samples (Karato, this volume), indicating that the bulk of hydrothermal flow occurs through fissures, cracks, and/or faults in basement rocks. That there appears to be a good correlation between presentday heat flow and the depth gradient of physical properties suggests that the pattern of hydrothermal circulation is fixed in location with respect to the moving plate, rather than fixed relative to the ridge axis (Fehn et al., in prep.).

From shipboard measurements of physical properties of disturbed sediments from the mounds, Hekinian, Rosendahl et al. (1978) concluded that the green clay sediments were denser and had higher in situ(?) sonic velocities than the associated pelagic oozes. The two reflectors that Lonsdale (1977) attributed to ash layers were interpreted by Natland et al. (1979) as corresponding to the impedance contrast between the top and bottom of the green smectite layer and the pelagic sediments. As a consequence, this "hydrothermal" layer was believed to extend continuously throughout the area of the mounds and into the entire heat-flow region beyond. We found only one ash layer in each of three holes out of twelve which were cored. Thus, regional extension of nontronitic clay layers or drastic change in the physical properties due to ash must be excluded as causes of the reflectors. Borella (this volume) suggests that the subbottom acoustic reflectors are the result of past climatic changes reflected in the sediment composition (slower sedimentation rates allowing concentrations of $\mathrm{Fe}$ and Mn to accumulate in oxygenated interglacial sediment layers) and diagenetic effects (silica dissolution as a result of reaction with hydrothermal solutions), which have changed the physical properties of the sediments thereby altering the acoustic impedance.

\section{CONCLUSIONS}

The successful drilling and sampling of the Galapagos hydrothermal mounds on Leg 70 provided many new data on their nature and origin. The most important conclusions from these data are the following:

1) The hydrothermal sediments contained in the mounds are limited in lateral distribution to the immediate vicinity $(<100 \mathrm{~m})$ of the mounds or mound ridges.

2) The stratigraphy of the hydrothermal deposits, composed primarily of Mn oxides overlying nontronite, both interbedded with and sandwiched between pelagic sediments, narrows the range of acceptable models of mounds formation. The slow interaction of hydrothermal solutions with pelagic sediments is preferred, rather than rapid debouchment of hydrothermal solution and precipitation of hydrothermal products onto the seafloor.

3) Thermal and chemical gradients in the sediments on and near the mounds indicate that hydrothermal solutions are presently active in the formation of the mounds. The mounds form in a few hundred thousand years or less.

4) The lack of hydrothermal alteration in the uppermost few meters of basement rocks in the Galapagos area is consistent with the generally low temperatures $\left(<35^{\circ} \mathrm{C}\right)$ presently found there. The hydrothermal solutions probably tap deeper (approximately $1 \mathrm{~km}$ ) rocks undergoing alteration at higher temperatures.

5) The requirements for the formation of the Galapagos mounds appear to be: (a) location near enough a spreading axis to be in a region of high heat flow containing convective discharge/recharge cells; (b) burial of topography beneath 20 to 50 meters of pelagic sediment before the crust spreads beyond the high heat-flow area (this requires a high rate of sedimentation because free discharge of hydrothermal solutions would prevent replacement of pelagic sediment by hydrothermal components); (c) a subdued basement topography so that hydrothermal solutions cannot discharge into seawater directly from exposed basement highs and fault scarps (this requires a relatively fast-spreading ridge, otherwise rugged basement topography is developed); and (d) a source of $\mathrm{O}_{2}$ within at least the upper portions of the mounds to cause precipitation and separation of nontronite and Mn-oxide phases.

\section{REFERENCES}

Allmendinger, R. W., and Riis, F., 1979. The Galapagos Rift at $86^{\circ} \mathrm{W}$ : Regional morphological and structural analysis. J. Geophys. Res., 84:5379-5389.

Anderson, R. N., Clague, D. A., Klitgord, K. D., Marshall, M., and Nishimori, R. K., 1975. Magnetic and petrologic variations along the Galapagos Spreading Center and their relation to the Galapagos melting anomaly. Geol. Soc. Am. Bull., 86:683-694.

Aoki, S., Kohyama, N., and Sudo, T., 1974. An iron-rich montmorillonite in a sediment core from the northeastern Pacific. Deep-Sea Res., 21:865-875.

Bender, M., Broecker, W., Gornitz, V., Middle, U., Kay, R., Sun, S.-S., and Biscay, P., 1971. Geochemistry of three cores from the East Pacific Rise. Earth Planet. Sci. Lett., 12:425-433.

Bischoff, J. L., 1969. Red Sea geothermal brine deposits: their mineralogy, chemistry, and genesis. In Degens, E. T. (Ed.), Recent Heavy Metal Deposits in the Red Sea: New York (Springer-Verlag), pp. 368-401. 
1972. A ferroan nontronite from the Red Sea geothermal system. Clays Clay Miner., 20:217-223.

Bischoff, J. L., and Rosenbauer, R. J., 1977. Recent metalliferous sediments in the North Pacific manganese nodule area. Earth Planet. Sci. Lett., 33:379-388.

Bonatti, E., Fisher, D. E., Joensuu, O., and Rydell, H. S., 1971. Postdepositional mobility of some transition elements, phosphorous, uranium and thorium in deep sea sediments. Geochim. Cosmochim. Acta., 35:189.

Bonatti, E., Fisher, D. E., Joensuu, O., Rydell, H. S., and Beyth, M., 1972. Iron-manganese-barium deposit from the Afar Rift (Ethiopia). Econ. Geol., 67:717-730.

Bonatti, E., Guerstein-Honnorez, B.-M., and Honnorez, J., 1976a. Copper-iron sulfide mineralization from the equatorial Mid-Atlantic Ridge. Econ. Geol., 71:1515-1525.

1976b. Hydrothermal pyrite concretions from the Romanche Trench (equatorial Atlantic): Metallogenesis in oceanic fracture zones. Earth Planet. Sci. Lett., 32:1-10.

Bonatti, E., and Joensuu, O. 1966. Deep-sea iron deposits from South Pacific. Science, 154:643-645.

Boström, K., 1973. The origin and fate of ferromanganoan active ridge sediments. Stockholm Contrib. Geol., 27(2):149-243.

Boström, K., Joensuu, O., Valdes, S., Charm, W., and Glaccum, R., 1976. Geochemistry and origin of East Pacific sediments sampled during DSDP Leg 34. In Yeats, R. S., Hart, S. R. et al., Init. Repts. DSDP, 34: Washington (U.S. Govt. Printing Office), 559-574.

Bredehoeft, J. D., and Papadopulos, I. S., 1965. Rates of vertical ground water movement estimated from the Earth's thermal profile. Water Resources Res., 1(2):325-328.

Cann, J. R., Winter, C. K., and Pritchard, R. G., 1977. A hydrothermal deposit from the floor of the Gulf of Aden. Mineral. Mag., 41:193-199.

Chou, T., J., and Patterson, C. C., 1962. The occurrence and significance of $\mathrm{Pb}$ isotopes in pelagic sediments. Geochim. Cosmochim. Acta., 26:263-308.

Clague, D. A., and Bunch, T. E., 1976. Formation of ferrobasalt at East Pacific mid-ocean spreading center. J. Geophys. Res., 81: 4247-4256.

Clague, D. A., Frey, F. A., et al., 1981. Minor and trace element geochemistry of volcanic rocks dredged from the Galapagos Spreading Center: Role of crystal fractionation and mantle heterogeneity. J. Geophys. Res., 86:9469-9482.

Corliss, J. B., Dymond, J. R., Gordon, L. I., Edmond, J. M., Von Herzen, R. P., Ballard, R. D., Green, K., Williams, D. L., Bainbridge, A., Crane, K., and van Andel, Tj. H., 1979a. Submarine thermal springs on the Galapagos Rift. Science, 203:1073-1083.

Corliss, J. B., Gordon, L. I., and Edmond, J. M., 1979b. Some implications of heat/mass ratios in Galapagos Rift hydrothermal fluids for models of seawater-rock interaction and the formation of oceanic crust. In Talwani, M., Harrison, C. G., and Hayes, D. E. (Eds.), Deep Sea Drilling Results in the Atlantic Ocean: Ocean Crust. Maurice Ewing Series 2 (Amer. Geophys. Union), pp. 391-402.

Corliss, J. B., Lyle, M., and Dymond, J., 1978. The chemistry of hydrothermal mounds near the Galapagos Rift. Earth Planet. Sci. Lett., 40:12-24.

Courtois, C., 1981. Rare earth element distribution in hydrothermal deposits from the FAMOUS and Galapagos areas-Comparison with metalliferous sediments. Mar. Geol., 39:1-14. (French)

Cronan, D. S., 1976. Basal metalliferous sediments from the eastern Pacific. Bull. Geol. Soc. Am., 87:928-934.

1980. Metallogenesis at oceanic spreading centers. J. Geol. Soc., 137:369-371.

Donnelly, T. W., 1980. Secondarily modified sediments of the eastern Pacific: Major-element chemistry of Sites 420, 424, and 425, Deep Sea Drilling Project, Leg 54. In Rosendahl, B. R., Hekinian, R. et al., Init. Repts. DSDP, 54: Washington (U.S. Govt. Printing Office), 329-338.

Dymond, J., Corliss, J. B., Cobler, R., Muratli, M., Chou, C., and Conard, R., 1980. Composition and origin of sediments recovered by deep drilling of sediment mounds, Galapagos Spreading Cen- ter. In Rosendahl, B. R., Hekinian, R. et al., Init. Repts. DSDP, 54: Washington (U.S. Govt. Printing Office), 377-385.

Dymond, J., Corliss, J. B., and Heath, G. R., 1977. History of metalliferous sedimentation at Deep Sea Drilling Site 319, in the southeastern Pacific. Geochim. Cosmochim. Acta, 41:741-753.

Dymond, J., Corliss, J. B., Heath, G. R., Field, C. W., Dasch, E. J., and Veeh, H. H., 1973. Origin of metalliferous sediments from the Pacific Ocean. Geol. Soc. Am. Bull., 84:3355-3372.

Edmond, J. M., Measures, C., Mangum, B., Grant, B., Schlater, F. R., Collier, R., and Hudson, A., 1979a. On the formation of metal-rich deposits at ridge crests. Earth Planet. Sci. Lett., 46: 19-30.

Edmond, J. M., Measures, C., McDuff, R. E., Chan, L. H., Collier, R., Grant, B., Gordon, L. I., and Corliss, J. B., 1979b. Ridge crest hydrothermal activity and the balances of the major and minor elements in the ocean: The Galapagos data. Earth Planet. Sci. Lett., 46:1-18.

Francheteau, F., Needham, H. D., Choukroune, P., Juteau, T., Seguret, M., Ballard, R. D., Fox, P. J., Normark, W., Carranza, A., Cordoba, D., Guerrero, J., Rangin, C., Bougault, H., Cambon, P., and Hekinian, R., 1979. Massive deep-sea sulfide ores discovered on the East Pacific Rise. Nature, 277:523-528.

Green, K. E., 1980. Geothermal processes at the Galapagos Spreading Center [Ph.D. dissert.]. Woods Hole Oceanographic Institution, Woods Hole, Mass.

Green, K. E., Von Herzen, R. P., and Williams, D. L., 1981. The Galapagos Spreading Center at $86^{\circ} \mathrm{W}$ : A detailed geothermal field study. J. Geophys. Res., 86:979-986.

Grill, E. V., Chase, R. L., MacDonald, R. D., and Murray, J. W., 1981. A hydrothermal deposit from Explorer Ridge in the northeast Pacific Ocean. Earth Planet. Sci. Lett., 52:142-150.

Hamilton, E. L., 1976. Variation of density and porosity with depth in deep-sea sediments. J. Sed. Petrol., 46:280-300.

Haymon, R. M., and Kastner, M., 1981. Hot spring deposits on the East Pacific Rise at $21^{\circ} \mathrm{N}$ : Preliminary description of mineralogy and genesis. Earth Planet. Sci. Lett., 53:363-381.

Hein, J. R., Yeh, H.-W., and Alexander, E., 1979. Origin of iron-rich montmorillonite from the manganese nodule belt of the north equatorial Pacific. Clays Clay Miner., 27:185-194.

Hekinian, R., Fevrier, M., Bischoff, J. L., Prot, P., and Shanks, W. C., 1980. Sulfide deposits from the East Pacific Rise near $21^{\circ} \mathrm{N}$. Nature, 207:1433-1444.

Hekinian, R., Rosendahl, B. R., Cronan, D. S., Dmitriev, Y., Fodor, R. V., Goll, R. M., Hoffert, M., Humphris, S. E., Mattey, D. P., Matland, J., Petersen, N., Roggenthen, W., Schrader, E. L., Srivastava, R. K., and Warren, N., 1978. Hydrothermal deposits and associated basement rocks from the Galapagos Spreading Center. Oceanolog. Acta 1:473-482.

Hey, R., Johnson, G. L., and Lowrie, A., 1977. Recent plate motions in the Galapagos area. Geol. Soc. Am. Bull., 88:1385-1403.

Hoffert, M., Perseil, A., Hekinian, R., Choukroune, P., Needham, H. D., Francheateau, J., and LePichon, X., 1978. Hydrothermal deposits sampled by diving saucer in Transform Fault "A" near $37^{\circ} \mathrm{N}$ on the Mid-Atlantic Ridge, FAMOUS area. Oceanolog. Acta 1:73-86.

Hoffert, M., Person, A., Courtois, C., Karpoff, A. M., and Trauth, D., 1980. Sedimentology, mineralogy and geochemistry of hydrothermal deposits from Holes 424, 424A, 424B and 424C (Galapagos Spreading Center). In Rosendahl, B. R., Hekinian, R. et al. Init. Repts. DSDP, 54: Washington (U.S. Govt. Printing Office), 339-376.

Honnorez, J., Von Herzen, R. P., Barrett, T., Becker, K., Bender, M., Borella, P., Hubberten, H.-W., Jones, S., Karato, S., Laverne, C., Levi, S., Migdisov, A., Moorby, S. A., and Schrader, E. L., 1981. Preliminary results of Deep Sea Drilling Project, Leg 70. Geol. Soc. Am. Bull., 92:457-472.

Houtz, R., and Ewing, J., 1976. Upper crustal structure as a function of plate age. J. Geophys. Res., 81:2490-2498.

Hyndman, R., Erickson, A., and Von Herzen, R. P., 1974. Geothermal measurements on Leg 26. In Davies, T. A., Luyendyk, B. P., et al., Init. Repts. DSDP, 26: Washington (U.S. Govt. Printing Office), 451-463. 
Irving, E., Robertson, W. A., and Aumento, S., 1970. The MidAtlantic Ridge near $45^{\circ} \mathrm{N}, 6$ : Remanent intensity, susceptibility and iron content of dredged samples. Can. J. Earth Sci., 7:226-238.

Johnson, H. P., and Atwater, T., 1977. A magnetic study of the basalts from the Mid-Atlantic Ridge at $37^{\circ}$ N. Geol. Soc. Am. Bull., $88: 637-642$.

Klitgord, K. D., and Mudie, J. D., 1974. The Galapagos Spreading Center: A near-bottom geophysical survey. Geophys. J. R. Astron. Soc., 38:563-586.

Lalou, C., Brichet, E., Ku, T. L., and Jahanno, C., 1977. Radiochemical, scanning electron microscope (SEM) and X-ray dispersive energy (EDAX) studies of a FAMOUS hydrothermal deposit. Mar. Geol., 24:245-258.

Levi, S., 1980. Magnetic properties of the oceanic crust at the Galapagos Spreading Center near $86^{\circ} \mathrm{W}$. EOS, 61:943. (Abstract)

Loder, T. C., Lyons, W. B., Murray, S., and McGuinness, H. B., 1978. Silicate in anoxic pore waters and oxidation effect during sampling. Nature, 273:373-374.

Lonsdale, P., 1977. Deep-tow observations at the mounds abyssal hydrothermal field, Galapagos Rift. Earth Planet. Sci. Lett., 36: 92-110.

Lupton, J. E., Kunkhammer, G. P., Normark, W. R., Haymond, R., MacDonald, K. C., Weiss, R. F., and Craig, H., 1980. Helium-3 and manganese at the $21^{\circ}$ East Pacific Rise hydrothermal site. Earth Planet. Sci Lett., 50:115-127.

MacDonald, K. C., Becker, K., Spiess, F. N., and Ballard, R. D., 1980. Hydrothermal heat flux of the "black smoker" vents on the East Pacific Rise. Earth Plant. Sci. Lett., 48:1-7.

McMurtry, G. M., and Yeh, H.-W., 1981. Hydrothermal clay mineral formation of East Pacific Rise and Bauer Basin sediments. Chem. Geol., 32:189-205.

Martini, E., 1971. Standard Tertiary and Quaternary calcareous nannoplankton zonation. In Farinacci, A. (Ed), Sec. Planktonic Conf. Proc.: Rome, pp. 739-785.

Mayer, L. A., 1979. Deep sea carbonates: acoustic, physical and stratigraphic properties. J. Sed. Pet., 49(3):819-836.

Moore, W. S., and Vogt, P. R., 1976. Hydrothermal manganese crusts from two sites near the Galapagos spreading axis. Earth Planet. Sci. Lett., 29:349-356.

Natland, J., Rosendahl, B., Hekinian, R., Dmitriev, Y., Fodor, R., Goll, R., Hoffert, M., Humphris, S., Mattey, D., Petersen, N., Roggenthen, W., Schrader, E., Srivastava, R., and Warren, N., 1979. Galapagos hydrothermal mounds: Stratigraphy and chemistry revealed by deep sea drilling. Science, 204:613-616.

Palmason, G., 1967. On heat flow in Iceland in relation to the MidAtlantic Ridge. In Bjornsson, S. (Ed.), Iceland and Mid-Ocean Ridges. Soc. Sci. Islandica (Reykjavik), 33:111-127.

Petersen N., and Roggenthen, W. M., 1980. Rock and paleomagnetism of Leg 54 basalts-East Pacific Rise and Galapagos area. In Rosendahl, B. R., Hekinian, R. et al., Init. Repts. DSDP, 54: Washington (U.S. Govt. Printing Office), 865-877.

Piper, D. Z., 1973. Origin of metalliferous sediment from the East Pacific Rise. Earth Planet. Sci. Lett., 19:75-82.

Ratcliffe, E. H., 1960. The thermal conductivities of ocean sediments. J. Geophys. Res., 65:1535-1541.
RISE Project Group, 1980. East Pacific Rise: Hot springs and geophysical experiments. Science, 207:1421-1433.

Rona, P. A., 1980. TAG hydrothermal field: Mid-Atlantic Ridge crest at latitude $26^{\circ}$ N. J. Geol. Soc., 137:385-402.

Rosendahl, B. R., Hekinian, R. et al., 1980. Init. Repts. DSDP, 54: Washington (U.S. Govt. Printing Office).

Savin, S. M., and Epstein, S., 1970. The oxygen and hydrogen isotope geochemistry of ocean sediments and shales. Geochim. Cosmochim. Acta, 34:43-63.

Sayles, F. I., and Bischoff, J. L., 1973. Ferromanganoan sediments in the equatorial East Pacific. Earth Planet. Sci. Lett., 18:330-336.

Schilling, J. G., Anderson, R. N., and Vogt, P., 1976. Rare earth, Fe and $\mathrm{Ti}$ variations along the Galapagos Spreading Center and their relationship to the Galapagos mantle plume. Nature, 261:108-113.

Schrader, E. L., Rosendahl, B. R., Furbish, W. J., and Mattey, D. P., 1980. Mineralogy and geochemistry of hydrothermal and pelagic sediments from the mounds hydrothermal field, Galapagos Spreading Center, Deep Sea Drilling Project, Leg 54. J. Sed. Petrol., 50(3):917-928.

Sclater, J. G., and Klitgord, K. D., 1973. A detailed heat flow, topographic and magnetic survey across the Galapagos Spreading Center at $85^{\circ}$ W. J. Geophys. Res., 78:6951-6975.

Sclater, J. G., Von Herzen, R. P., Williams, D. L., Anderson, R. N., and Klitgord, K., 1974. The Galapagos Spreading Center: Heatflow low on the north flank. Geophys. J. R. Astron. Soc., 38: 609-626.

Scott, M. R., Scott, R. B., Rona, P. A., Butler, L. W., and Nalwalk, A. J., 1974. Rapidly accumulating manganese deposit from the median valley of the Mid-Atlantic Ridge. Geophys. Res. Lett., $1: 335-358$.

Skornyakova, I. S., 1964. Rasseyannyye zhelezo i marganets v osadkekh Tikhogo Okeana. Lithol. Miner. Resear., 5:3-20.

Spooner, E. T. C., and Fyfe, W. S., 1973. Sub-sea floor metamorphism, heat and mass transfer. Contrib. Mineral. Petrol., 42: 287-304.

Toth, J. R., 1980. Deposition of submarine crusts in manganese and iron. Geol. Soc. Am. Bull., 91:44-54.

Turekian, K. K., and Wedepohl, K. H., 1961. Distribution of the elements in some major units of the Earth's crust. Geol. Soc. Am. Bull., 72:175-192.

Von Herzen, R., and Maxwell, A. E., 1959. The measurement of thermal conductivity of deep sea sediments by a needle probe method. J. Geophys. Res., 64:1557-1563.

Williams, D. L., Green, K., van Andel, Tj. H., Von Herzen, R. P., Dymond, J. R., and Crane, K., 1979. The hydrothermal mounds of the Galapagos Rift: Observations with DS R/V Alvin and detailed heat flow studies. J. Geophys. Res., 84(B13):7467-7484.

Williams, D. L., Von Herzen, R. P., Sclater, J. G., and Anderson, R. N., 1974. The Galapagos Spreading Center: Lithospheric cooling and hydrothermal circulation. Geophys. J. R. Astron. Soc., 38:587-608.

Yeh, H.-W., and Savin, S. M., 1977. Mechanism of burial metamorphism of argillaceous sediments: 3. 0-isotope evidence. Geol. Soc. Am. Bull., 88:1321-1330. 